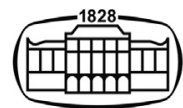

AKADÉMIAI KIADÓ

Central European

Geology

63 (2020) 1, 1-18

DOI:

$10.1556 / 24.2020 .00003$

(c) 2020 The Author(s)

ORIGINAL ARTICLE

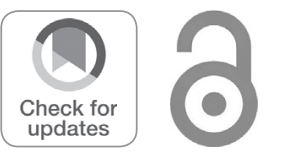

*Corresponding author. 'Vulcano' Petrology and Geochemistry Research Group, Department of Mineralogy, Geochemistry and Petrology, University of Szeged, Egyetem u. 2, H-6722, Szeged, Hungary.

E-mail: szemeredi.mate@gmail.com

\section{Lavas or ignimbrites? Permian felsic volcanic rocks of the Tisza Mega-unit (SE Hungary) revisited: A petrographic study}

\author{
MÁTÉ SZEMERÉDI ${ }^{1,2 *}$ (1), ANDREA VARGA ${ }^{1}$, \\ JÁNOS SZEPESI ${ }^{2,3}$, ELEMÉR PÁL-MOLNÁR ${ }^{1,2}$ and \\ RÉKA LUKÁCS ${ }^{1,2}$
}

\author{
1 'Vulcano' Petrology and Geochemistry Research Group, Department of Mineralogy, Geochemistry \\ and Petrology, University of Szeged, Szeged, Hungary \\ ${ }^{2}$ MTA-ELTE Volcanology Research Group, Budapest, Hungary \\ ${ }^{3}$ Isotope Climatology and Environmental Research Centre (ICER), Institute of Nuclear Research, \\ Hungarian Academy of Sciences, Debrecen, Hungary
}

Received: May 02, 2019 • Accepted: December 28, 2019

Published online: August 28, 2020

\begin{abstract}
Permian felsic volcanic rocks were encountered in petroleum exploration boreholes in SE Hungary (eastern Pannonian Basin, Tisza Mega-unit, Békés-Codru Unit) during the second half of the 20th century. They were considered to be predominantly lavas (the so-called "Battonya quartz-porphyry") and were genetically connected to the underlying "Battonya granite." New petrographic observations, however, showed that the presumed lavas are crystal-poor (8-20 vol\%) rhyolitic ignimbrites near Battonya and resedimented pyroclastic or volcanogenic sedimentary rocks in the Tótkomlós and the Biharugra areas, respectively. The studied ignimbrites are usually massive, matrix-supported, fiammebearing lapilli tuffs with eutaxitic texture as a result of welding processes. Some samples lack vitroclastic matrix and show low crystal breakage, but consist of oriented, devitrified fiammes as well. Textural features suggest that the latter are high-grade rheomorphic ignimbrites.

Felsic volcanic rocks in SE Hungary belong to the Permian volcanic system of the Tisza Mega-unit; however, they show remarkable petrographic differences as compared to the other Permian felsic volcanic rocks of the mega-unit. In contrast to the crystal-poor rhyolitic ignimbrites of SE Hungary with rare biotite, the predominantly rhyodacitic-dacitic pyroclastic rocks of the Tisza Mega-unit are crystalrich (40-45 vol\%) and often contain biotite, pyroxene, and garnet. Additionally, some geochemical and geochronological differences between them were also observed by previous studies. Therefore, the Permian felsic volcanic rocks in SE Hungary might represent the most evolved, crystal-poor rhyolitic melt of a large-volume felsic (rhyodacitic-dacitic) volcanic system.

The Permian volcanic rocks of the studied area do not show any evident correlations with either the Permian felsic ignimbrites in the Finiş Nappe (Apuseni Mts, Romania), as was supposed so far, or the similar rocks in any nappe of the Codru Nappe System. Moreover, no relevant plutonic-volcanic connection was found between the studied samples and the underlying "Battonya granite."
\end{abstract}

\section{KEYWORDS}

battonya, felsic volcanism, ignimbrite, lava, permian, volcaniclastite

\section{INTRODUCTION}

Permo-Carboniferous large-volume silicic magmatism is a common feature of the European Variscides that was genetically controlled by a post-collisional to extensional tectonic setting (Cortesogno et al. 1998; Awdankiewicz 1999; Wilson et al. 2004; Paulick and Breitkreuz 2005; Vozárová et al. 2009, 2015, 2016; Seghedi 2010; Wilcock et al. 2013; Letsch et al. 2014; 
Nicolae et al. 2014; Repstock et al. 2017; Ondrejka et al. 2018). Permian volcanic rocks associated with such magmatic activity are well-known in the Tisza Mega-unit (Tisza MU, Pannonian Basin; Fig. 1a) and exposed in several outcrops (Apuseni Mts, Romania, and Western Mecsek Mts, Hungary) and by boreholes (southern Transdanubia and the eastern Pannonian Basin, Hungary), representing all three Alpine facies zones of the Tisza MU (Mecsek, Villány-Bihor, and Békés-Codru Units; Fig. 1b; Szederkényi 1962; BarabásStuhl 1988; Hidasi et al. 2015; Szemerédi et al. 2016, 2017, 2020). Based on petrographic, whole-rock geochemical (including major and trace elements), and geochronological (zircon U-Pb ages) results all Permian felsic volcanic rocks within the Tisza MU are the products of the same volcanic epoch (266.8 $\pm 2.7-259.5 \pm 2.6 \mathrm{Ma}$; Szemerédi et al. 2020).

Ancient volcanic rocks might have undergone various processes of syn- and post-volcanic alteration; thus, it could be a real challenge to determine their original volcanic facies. Primary textural features could have been overprinted or modified, making the genetic interpretation (e.g., pyroclastic rock or lava) of such rocks a difficult task for volcanologists (e.g., Allen 1988; Branney and Kokelaar 1992; Branney et al. 1992; Henry and Wolff 1992; Gifkins et al. 2005a, b). The incomplete destruction of primary textures and the different alteration styles can also have resulted in the development of false textures or pseudotextures. Thus, false pyroclastic textures (false shards, false eutaxitic texture) as well as false massive textures can have been formed, usually causing significant difficulties in the reliable interpretation of ancient volcanic rocks (Allen 1988; Gifkins et al. 2005a, b).

Permian felsic volcanic rocks of the Hungarian part of the Tisza MU were previously described and interpreted in the reports of uranium ore (southern Transdanubia) and petroleum (SE Hungary) exploration work during the second half of the 20th century (e.g., Barabás-Stuhl 1988; Fülöp 1994; Körössy 2005a, b). According to the archive reports the rocks were considered to be dominantly lavas ("quartzporphyry" using the appropriate paleovolcanic name; Szederkényi 1962; Szepesházy 1967; Barabás-Stuhl 1988; Körössy 2005a, b); however, modern petrographic observations (e.g., Hidasi et al. 2015; Szemerédi et al. 2016, 2017) reinterpreted most of them as ignimbrites in the area of southern Transdanubia. In a similar way such a (re)examination of the Permian felsic volcanic rocks in SE Hungary was also required.

Three main subsurface areas of the Permian felsic volcanic rocks can be distinguished within southern Transdanubia: (i) the Western Mecsek Mts, (ii) the Máriakéménd-Báta Basement Range (Máriakéménd-Báta $\mathrm{BR}$ ), and (iii) the northern foreland of the Villány Mts (Fig. 1a; Barabás-Stuhl 1988; Szemerédi et al. 2016, 2017). The Western Mecsek Mts and the Máriakéménd-Báta BR are represented by crystal-rich fiamme-bearing rhyodaciticdacitic ignimbrites, while in the northern foreland of the Villány Mts such ignimbrites and subordinate felsic lavas occur (Szemerédi et al. 2016, 2017, 2020). In the Apuseni Mts (Fig. 1a; Codru and Biharia Nappe Systems) rhyodacitic-dacitic ignimbrites are present; however, they are accompanied by mafic-to-intermediate lavas (basalt and subordinate andesite) as the result of a mainly bimodal volcanic activity (Codru Nappe System; Nicolae et al. 2014; Szemerédi et al. 2018).

Detailed petrographic studies have not targeted the Permian felsic volcanic rocks of the eastern Pannonian Basin (Battonya-Pusztaföldvár Basement Ridge and Kelebia area, Hungary; Fig. 1a). These rocks were briefly described in the

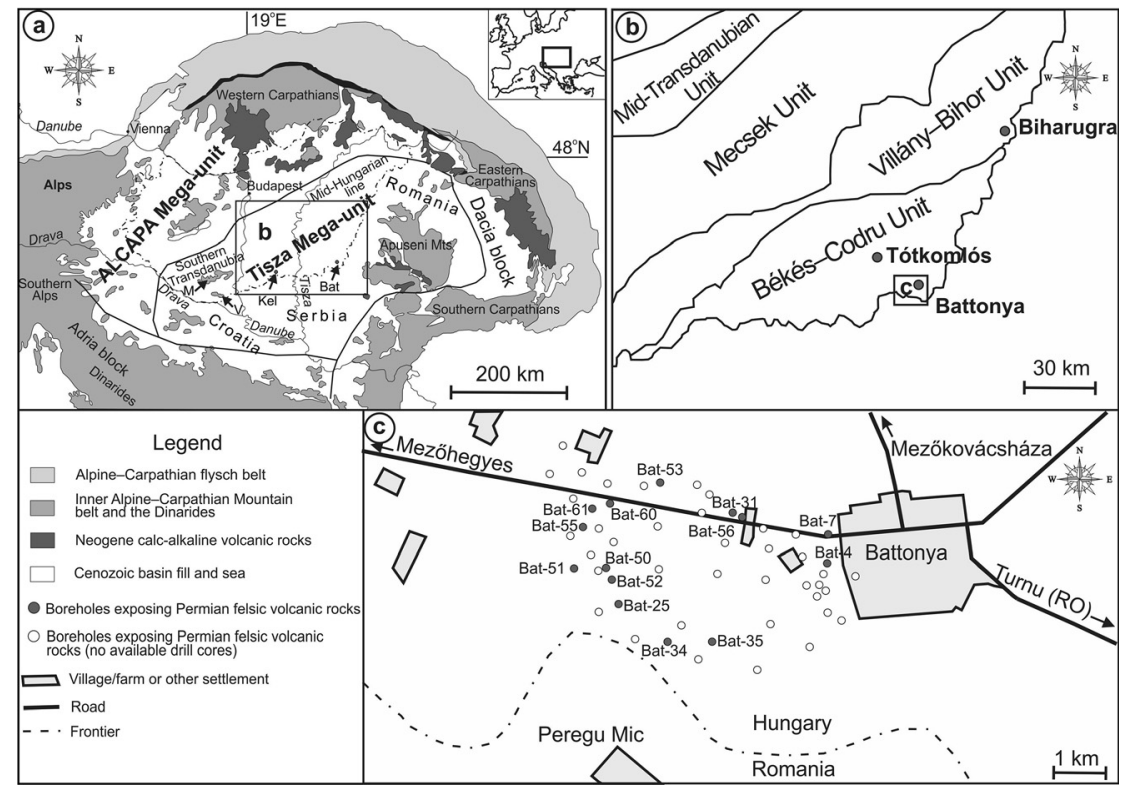

Figure 1. Tectonic sketch of the Pannonian Basin, pointing out the surface and subsurface distribution of the Permian felsic volcanic rocks (a), highlighting the subsurface occurrences in SE Hungary (b), especially in the Battonya area (c). Map base is modified after Szemerédi et al. (2020). Abbreviations: Bat: Battonya, Kel: Kelebia, M: Mecsek Mts, V: Villány Mts 
previous reports of hydrocarbon exploration (Szepesházy 1967; Körössy 2005a, b). Geochemically, all of the Permian felsic volcanic rocks in the Tisza MU show similar general characteristics. Nevertheless, some weak chemical differences were observed in the samples of the Battonya-Pusztaföldvár Basement Ridge (Battonya-Pusztaföldvár BR) that are rhyolites according to the immobile element-based rock classification $\left(\mathrm{Zr} / \mathrm{TiO}_{2}\right.$ vs. $\left.\mathrm{Nb} / \mathrm{Y}\right)$, while the others are rhyodacites-dacites (Szemerédi et al. 2020). Moreover, felsic pyroclastic rocks in SE Hungary proved to be slightly younger than other Permian volcanic rocks of the Tisza MU (Szemerédi et al. 2020).

The aim of this study is to provide a detailed petrographic description of the Permian felsic volcanic rocks of SE Hungary, using all available drill cores and thin sections from the boreholes near the villages of Battonya, Biharugra, and Tótkomlós (Fig. 1b and c). Furthermore, we attempt to interpret the former and new descriptions in the light of modern volcanological views of the ancient, altered volcanic sequences (e.g., Gifkins et al. 2005a, b).

\section{Geologic background}

In SE Hungary, ca. 50 boreholes (near the villages of Battonya, Biharugra, Kelebia, Mezőkovácsháza, Nagyszénás, Pitvaros, Pusztaföldvár, Tótkomlós, and Végegyháza) of hydrocarbon exploration work penetrated felsic volcanic rocks, predominantly within the Battonya-Pusztaföldvár BR (Figs 1c and 2; Szepesházy 1967; T. Kovács and Kurucz 1984;
Császár 2005; Körössy 2005a, b). The highest density of drilling is represented by the $c a .60 \mathrm{~km}^{2}$ Battonya area (Fig. 1c) and most of the materials of the presented study derive from there (Szepesházy 1967; Császár 2005; Körössy 2005a). The Permian felsic volcanic rocks are collectively named the Gyürüfü Rhyolite Formation in the Hungarian lithostratigraphic literature and they form the regionally most widespread Permian formation (Fülöp 1994; Császár 2005; Szemerédi et al. 2020). Stratigraphically, the basement of the volcanic rocks consists of Permian continental red beds (Korpád Sandstone Formation) but they are also often underlain by Variscan metamorphic rocks (two-mica schist and gneiss) or S-type granites ("Battonya granite," Fig. 2; T. Kovács and Kurucz 1984; Fülöp 1994; Császár 2005; Körössy 2005a, b). The overlying formation is the Triassic Jakabhegy Sandstone; however, in most cases the volcanic rocks are covered by much younger Cenozoic sediments (e.g., Miocene sandstone). The Permian felsic volcanic rocks were penetrated in their greatest thickness in the TótkomlósI borehole ( 400 m, Fig. 2; Császár 2005; Körössy 2005a). According to the archive reports the felsic volcanic rocks in SE Hungary were described as "quartz-porphyry" and predominantly interpreted as lavas or subvolcanic rocks with subordinate amounts of pyroclastics (Szepesházy 1967; Fülöp 1994; Császár 2005; Kőrössy 2005a, b). A volcanicplutonic connection was also supposed between the Permian volcanic rocks (thought to be dykes or lavas) and the underlying "Battonya granite" (thought to be Variscan) despite

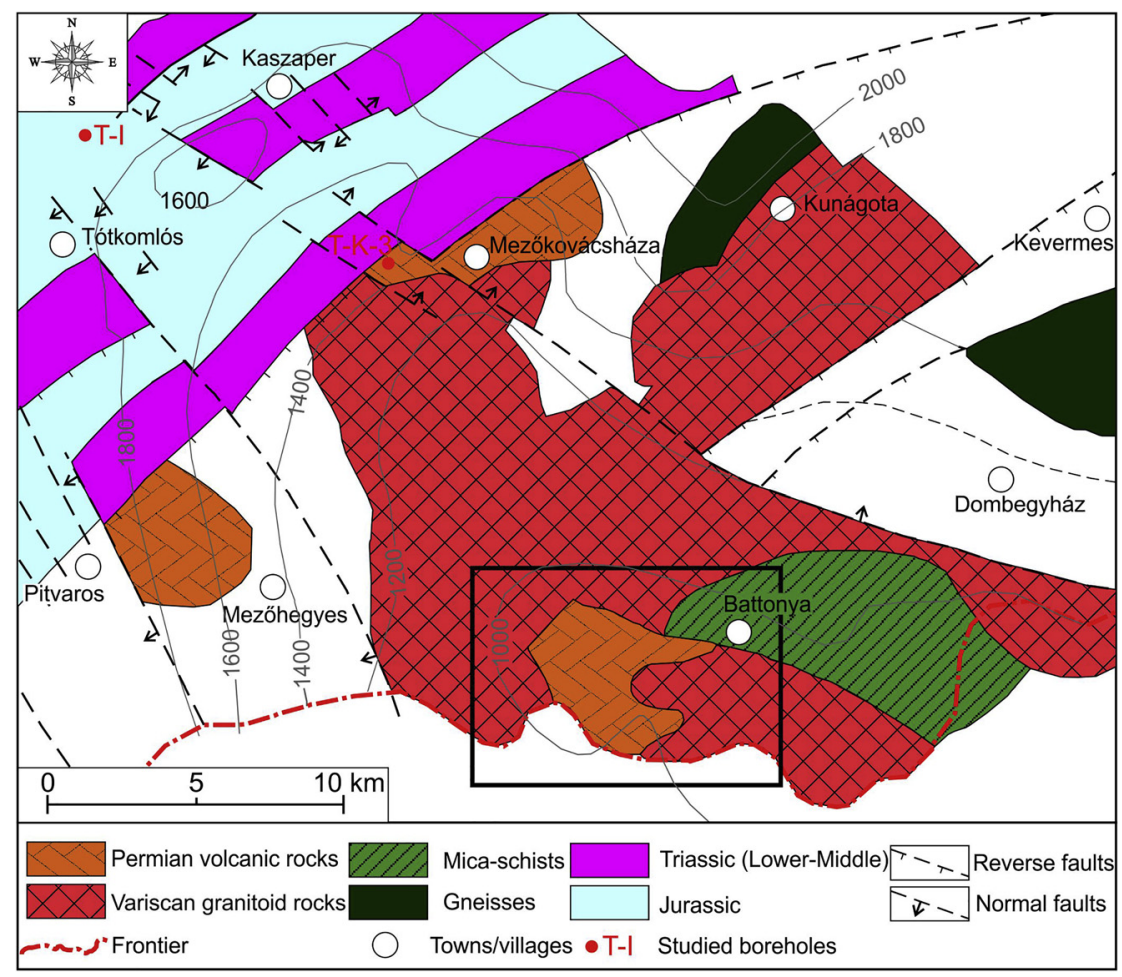

Figure 2. Basement formations in the eastern Pannonian Basin (SE Hungary, Tisza Mega-unit, Békés-Codru Unit), pointing out the Battonya area (black rectangle) and two of the studied boreholes. Abbreviations: T-I: Tótkomlós-I, T-K-3: Tótkomlós-K-3 (modified after Kurucz 1977; T. Kovács and Kurucz 1984) 
Table 1. The most important data of the studied samples and boreholes in SE Hungary and the summary of the results of the archive reports and this study. Samples with available whole-rock (major and trace elements) geochemical data are put in italics and bold while samples with zircon U-Pb ages are highlighted by asterisk (data in Szemerédi et al. 2020). Lithofacies (Lf) description are listed in Table 2

\begin{tabular}{|c|c|c|c|c|c|c|}
\hline \multirow[b]{2}{*}{ Sample code } & \multirow[b]{2}{*}{ Borehole (core) } & \multirow[b]{2}{*}{ Depth } & \multirow[b]{2}{*}{ Total depth } & \multirow[b]{2}{*}{ Previous name } & \multicolumn{2}{|c|}{ This study } \\
\hline & & & & & Lithology & Lf \\
\hline ÁGK-1790 & Battonya-4 (4) & $1020.4-1025.5 \mathrm{~m}$ & $1044.0 \mathrm{~m}$ & felsitic quartz-porphyry & pyroclastic & rheoLT \\
\hline ÁGK-1790-2 & Battonya-4 (4) & $1020.4-1025.5 \mathrm{~m}$ & $1044.0 \mathrm{~m}$ & felsitic quartz-porphyry & pyroclastic & rheoLT \\
\hline Bat-7 (Via-79) & Battonya-7 & $1058.0-1058.2 \mathrm{~m}$ & $1060.0 \mathrm{~m}$ & quartz-porphyry & pyroclastic & accfrichT \\
\hline ÁGK-1798 & Battonya-25 (2) & $1026.0-1031.0 \mathrm{~m}$ & $1042.0 \mathrm{~m}$ & felsitic quartz-porphyry & pyroclastic & rheoLT \\
\hline ÁGK-1799 & Battonya-25 (3) & $1031.0-1034.0 \mathrm{~m}$ & $1042.0 \mathrm{~m}$ & felsitic quartz-porphyry & pyroclastic & rheoLT \\
\hline ÁGK-1802 & Battonya-31 (3) & $1029.5-1031.0 \mathrm{~m}$ & $1044.0 \mathrm{~m}$ & felsitic quartz-porphyry & pyroclastic & rheoLT \\
\hline ÁGK-1243 & Battonya-34 & $1029.0-1030.5 \mathrm{~m}$ & $1042.0 \mathrm{~m}$ & quartz-porphyry & pyroclastic & rheoLT \\
\hline ÁGK-1271 & Battonya-35 (6) & $1058.0-1062.0 \mathrm{~m}$ & $1066.0 \mathrm{~m}$ & felsite & pyroclastic & emLT \\
\hline ÁGK-1818 & Battonya-50 (1) & $1020.0-1023.0 \mathrm{~m}$ & $1053.0 \mathrm{~m}$ & felsite & pyroclastic & emLT \\
\hline ÁGK-1274 & Battonya-50 (2) & $1053.0 \mathrm{~m}$ & $1053.0 \mathrm{~m}$ & quartz-porphyry & pyroclastic & rheoLT \\
\hline ÁGK-1819 & Battonya-51 (2) & $1023.0-1024.5 \mathrm{~m}$ & $1050.0 \mathrm{~m}$ & felsite & pyroclastic & emLT \\
\hline ÁGK-1821 & Battonya-51 (4) & $1027.2-1028.0 \mathrm{~m}$ & $1050.0 \mathrm{~m}$ & felsite & pyroclastic & emLT \\
\hline ÁGK-1823 & Battonya-52 (1) & $1022.0-1024.0 \mathrm{~m}$ & $1050.0 \mathrm{~m}$ & felsitic quartz-porphyry & pyroclastic & rheoLT \\
\hline$A ́ G K-1824$ & Battonya-52 (2) & $1032.0-1033.5 \mathrm{~m}$ & $1050.0 \mathrm{~m}$ & felsitic quartz-porphyry & pyroclastic & rheoLT \\
\hline ÁGK-1825 & Battonya-53 (2) & $1028.6-1033.0 \mathrm{~m}$ & $1050.0 \mathrm{~m}$ & quartz-porphyry & pyroclastic & rheoLT \\
\hline ÁGK-1828-1 & Battonya-55 (2) & $1025.0-1028.0 \mathrm{~m}$ & $1050.0 \mathrm{~m}$ & quartz-porphyry & pyroclastic & rheoLT \\
\hline ÁGK-1828-2 & Battonya-55 (2) & $1025.0-1028.0 \mathrm{~m}$ & $1050.0 \mathrm{~m}$ & quartz-porphyry & pyroclastic & rheoLT \\
\hline$A ́ G K-1830$ & Battonya-56 (3) & $1033.5-1034.5 \mathrm{~m}$ & $1045.0 \mathrm{~m}$ & quartz-porphyry & pyroclastic & emLT \\
\hline ÁGK-1831 & Battonya-60 (2) & $1025.0-1027.0 \mathrm{~m}$ & $1045.0 \mathrm{~m}$ & felsite & pyroclastic & emLT \\
\hline ÁGK-1833 & Battonya-61 (3) & $1028.0-1031.0 \mathrm{~m}$ & $1053.0 \mathrm{~m}$ & quartz-porphyry & pyroclastic & rheoLT \\
\hline ÁGK-1339 & Biharugra-I (20) & $3157.0-3158.0 \mathrm{~m}$ & $3200.0 \mathrm{~m}$ & quartz-porphyry & pyroclastic & $\operatorname{lmLT}$ \\
\hline ÁGK-1340 & Biharugra-I (21) & $3198.0-3198.5 \mathrm{~m}$ & $3200.0 \mathrm{~m}$ & ignimbrite & pyroclastic & $\operatorname{lmLT}$ \\
\hline ÁGK-1340-2 & Biharugra-I (21) & $3198.0-3198.5 \mathrm{~m}$ & $3200.0 \mathrm{~m}$ & ignimbrite & pyroclastic & $\operatorname{lmLT}$ \\
\hline $\mathrm{BATR} / 1^{\star}$ & Tótkomlós-K-3 & $1669.0-1674.0 \mathrm{~m}$ & $1686.0 \mathrm{~m}$ & quartz-porphyry & pyroclastic & $\operatorname{lmLT}$ \\
\hline$B A T R / 2^{\star}$ & Tótkomlós-K-3 & $1669.0-1674.0 \mathrm{~m}$ & $1686.0 \mathrm{~m}$ & quartz-porphyry & pyroclastic & $\operatorname{lmLT}$ \\
\hline ÁGK-1267 & Tótkomlós-K-3 (17) & $1669.0-1674.0 \mathrm{~m}$ & $1686.0 \mathrm{~m}$ & quartz-porphyry & pyroclastic & $\operatorname{lmLT}$ \\
\hline T-I $13 \mathrm{MF}$ & Tótkomlós-I (13) & $3248.0-3249.0 \mathrm{~m}$ & $3998.0 \mathrm{~m}$ & quartz-porphyry & pyroclastic or lava & vlava-likeT \\
\hline T-I $14 \mathrm{MF}$ & Tótkomlós-I (14) & $3267.0-3268.0 \mathrm{~m}$ & $3998.0 \mathrm{~m}$ & quartz-porphyry & pyroclastic or lava & vlava-likeT \\
\hline T-I $15 \mathrm{MF}$ & Tótkomlós-I (15) & $3402.0-3404.0 \mathrm{~m}$ & $3998.0 \mathrm{~m}$ & quartz-porphyry & pyroclastic or lava & vlava-likeT \\
\hline
\end{tabular}

Table 2. Terminology used for the characterization of the lithofacies of the Permian felsic volcanic rocks in SE Hungary (modified after Branney and Kokelaar 2002; Sommer et al. 2013)

\begin{tabular}{|c|c|}
\hline Facies code & Lithofacies description \\
\hline emLT & $\begin{array}{l}\text { Eutaxitic, massive, matrix-supported, } \\
\text { porphyric, fiamme-bearing lapilli tuffs }\end{array}$ \\
\hline rheoLT & $\begin{array}{l}\text { Felsitic, matrix-supported, porphyric, fiamme- } \\
\text { bearing rheomorphic lapilli tuffs }\end{array}$ \\
\hline accfrichT & $\begin{array}{l}\text { Matrix-supported, fine-grained, felsitic ash tuff } \\
\text { with coated particles }\end{array}$ \\
\hline $\operatorname{lmLT}$ & $\begin{array}{l}\text { Lithic-rich, massive, strongly sericitized, } \\
\text { poorly-sorted volcaniclastics }\end{array}$ \\
\hline vlava-likeT & Spherulitic vitrophyric lava-like ash tuffs \\
\hline
\end{tabular}

the absence of any geochemical or geochronological evidence (Szepesházy 1967). Based on the strongly similar stratigraphic column of the Tótkomlós-I borehole (i.e., between 2,693 and 3,998 m beneath the surface: Mesozoic sedimentary rocks, Permian volcanic rocks and continental red beds, possible Precambrian granites; Körössy 2005a), the Battonya-Pusztafödvár BR was correlated with the Finiş
Nappe of the Codru Nappe System (Codru NS), Apuseni Mts, Romania (Szepesházy 1979; Császár 2005; Körössy 2005a). Recently, however, Nicolae et al. (2014) documented crystal-rich, garnet-bearing pyroclastic rocks in the Finiş Nappe, that suggests differences when compared to the Permian volcanic rocks of the aforementioned areas.

\section{MATERIALS AND METHODS}

During the second half of the 20th century, hundreds of boreholes were drilled by the legal forerunner of the Hungarian Oil \& Gas Company Plc (MOL Rt.) in the eastern Pannonian Basin (Hungary) in order to explore hydrocarbon reservoirs (Szepesházy 1967; Császár 2005; Kőrössy 2005a, b). The drilling usually ended in Permian felsic volcanic rocks, representing the Paleozoic basement of the Tisza MU (Fig. 2). Drill cores from 17 boreholes (2-3 pieces/ borehole) and 29 thin sections from three subsurface occurrences of the Permian felsic volcanic rocks, namely the Battonya, the Biharugra, and the Tótkomlós areas, have been available for the present study at the Department of 
Mineralogy, Geochemistry and Petrology, University of Szeged (Table 1; Fig. 1b). The most important data of the sampling sites and the investigated thin sections are summarized in Tables 1 and 2. The studied boreholes in the Battonya area are also highlighted in Fig. 1c.

Petrographic studies, including mineralogical and textural observations, were conducted on hand specimen and thin sections. In this study, modal compositions (vol\%) were generally estimated based on micropetrography. Nevertheless, modal (volume) proportions of rock-forming minerals, fragments, as well as groundmass were also measured, quantitatively at least, on one selected representative sample of each distinct lithofacies, using a grid of 500 cells for each measurement (Table 3 ). The terminology used in the petrographic descriptions and interpretations were derived from the following principal references:

Table 3. Modal (volume) proportions (in \%) of rock-forming minerals, fiammes, as well as the groundmass, measured quantitatively at least, on one selected representative sample of each distinct lithofacies. The meaning of the abbreviations applied for the lithofacies (facies code) are described in Table 2. Abbreviations: bt: biotite, cp: coated particle, f: fiamme, g: groundmass, kfs: K-feldspar, $\mathrm{L}_{\mathrm{v}}$ : volcanic lithic clast, $\mathrm{L}_{\mathrm{nv}}$ : non-volcanic lithic clast, pl: plagioclase, qz: quartz. ${ }^{\star}$ In the case of lithic-rich, massive, strongly sericitized, poorly-sorted volcaniclastics strongly sericitized groundmass and altered juvenile fragments (fiammes and glass shards) were indistinguishable and given together as groundmass

\begin{tabular}{lccllllllll}
\hline Sample & Lithofacies & $\mathrm{qz}$ & $\mathrm{kfs}$ & $\mathrm{pl}$ & $\mathrm{bt}$ & $\mathrm{f}$ & $\mathrm{g}$ & $\mathrm{L}_{\mathrm{v}}$ & $\mathrm{L}_{\mathrm{nv}}$ & $\mathrm{cp}$ \\
\hline ÁGK-1821 & emLT & 3.5 & 3 & 1.8 & 0 & 11.5 & 80.2 & 0 & 0 & 0 \\
ÁGK-1830 & emLT & 7.5 & 4.9 & 5 & 0.1 & 9.6 & 72.9 & 0 & 0 & 0 \\
ÁGK-1828-2 & rheoLT & 12 & 4.6 & 3.1 & 0 & 9.9 & 70.4 & 0 & 0 & 0 \\
Bat-7 (Via-79) & accfrichT & 2.1 & 7.9 & 0 & 0 & 0 & 89.0 & 0 & 0 & 1.0 \\
ÁGK-1340 & lmLT & 8.3 & 4 & 1.8 & 0.1 & $*$ & 69.3 & 14.5 & 0 & 0 \\
BATR/1 & lmLT & 9.3 & 1.3 & 0.7 & 0 & $*$ & 76.4 & 8.2 & 4.1 & 0 \\
T-I 14 MF & vlava-likeT & 5.5 & 4.1 & 0.4 & 0 & 0 & 90.2 & 0 & 0 & 0 \\
\hline
\end{tabular}

Table 4. Table of the most significant terms used in the petrographic descriptions and interpretations, explaining their meaning. Some references are given for each expression

\begin{tabular}{|c|c|c|}
\hline Term & Meaning & References \\
\hline Axiolite & $\begin{array}{l}\text { Product of high-temperature } \\
\text { devitrification of silicic glass. Spherulitic } \\
\text { aggregate arranged at right angles to } \\
\text { central axis rather than from a point }\end{array}$ & Gifkins et al. (2005b) \\
\hline Coated particles & $\begin{array}{l}\text { Fragile aggregates comprised of a } \\
\text { crystal, crystal fragment, pumice or } \\
\text { lithic clast partially covered in fine ash } \\
\text { particles }\end{array}$ & Brown et al. (2012) \\
\hline Eutaxitic texture & $\begin{array}{l}\text { Pre-tectonic foliation defined by the } \\
\text { parallel alignment of fiammes }\end{array}$ & Gifkins et al. (2005a,b) \\
\hline Felsitic texture & $\begin{array}{l}\text { Igneous texture comprised of a very } \\
\text { fine-grained groundmass of mosaic } \\
\text { quartz and alkali feldspar crystals }\end{array}$ & MacKenzie et al. (1982) \\
\hline Fiamme & $\begin{array}{l}\text { Flame-like, glassy or devitrified lenses, } \\
\text { which define a pre-tectonic foliation }\end{array}$ & Gifkins et al. (2005a,b) \\
\hline Lava-like & $\begin{array}{l}\text { Extremely high-grade (intensely } \\
\text { welded) ignimbrite lithofacies that is } \\
\text { texturally indistinguishable from lava }\end{array}$ & $\begin{array}{c}\text { Branney et al. (1992); Branney and } \\
\text { Kokelaar (1992) }\end{array}$ \\
\hline Rheomorphic & $\begin{array}{l}\text { Any non-particulate flow structure that } \\
\text { formed prior to lithification }\end{array}$ & $\begin{array}{c}\text { Branney et al. (1992); Branney and } \\
\text { Kokelaar (1992) }\end{array}$ \\
\hline Spherulite & $\begin{array}{c}\text { Product of high-temperature } \\
\text { devitrification of silicic glass. Radiating } \\
\text { aggregates or bundles of acicular and } \\
\text { fibrous crystals }\end{array}$ & $\begin{array}{l}\text { Lofgren (1971); Gifkins et al. (2005b); } \\
\text { Breitkreuz (2013) }\end{array}$ \\
\hline Vitroclastic texture & $\begin{array}{l}\text { Pyroclastic texture that is composed of } \\
\text { glass fragments cemented by glass }\end{array}$ & $\begin{array}{c}\text { Branney et al. (1992); Branney and } \\
\text { Kokelaar (1992) }\end{array}$ \\
\hline Vitrophyric texture & $\begin{array}{l}\text { Inequigranular volcanic texture in } \\
\text { which larger crystals (porphyres) are } \\
\text { embedded in glassy groundmasss }\end{array}$ & Gifkins et al. (2005b) \\
\hline
\end{tabular}


Branney and Kokelaar (1992), Branney et al. (1992), Henry and Wolff (1992), McPhie et al. (1993), Branney and Kokelaar (2002), Gifkins et al. (2005a, b), Paulick and Breitkreuz (2005), Brown et al. (2012), and Breitkreuz (2013). The most important terms used in the petrographic descriptions and interpretations as well as the abbreviations of each lithofacies name are summarized in Tables 2 and 4 , respectively.

\section{RESULTS}

Based on the petrographic observations, five distinct lithofacies can be distinguished among the volcanic rock samples (Table 2) which are separately described and interpreted below.

\section{Eutaxitic, massive, matrix-supported, porphyric, fiamme-bearing lapilli tuffs (emLT)}

The presence of the emLT lithofacies was demonstrated in five boreholes in the study area, namely wells Battonya-35, Battonya-50, Battonya-51, Battonya-56, and Battonya-60 (see details in Table 1) in the Battonya-Pusztaföldvár BR, Békés-Codru Unit (Fig. 1c).

Description. Felsic rocks are purplish or greenish gray in color, and can be classified as massive, non-porous matrixsupported lapilli tuffs that consist of macroscopically dark, flattened, devitrified fiammes (10-12 vol\%), usually $\mathrm{mm}$ in size, together with various poorly-sorted and fragmented phenocrysts $(8-18 \mathrm{vol} \%)$ in a fine groundmass of predominantly quartz and feldspar (73-80 vol\%).

Well-visible oriented texture (Fig. 3) is defined by deformed, devitrified glass shards (from $\sim 100 \mu \mathrm{m}$ up to the
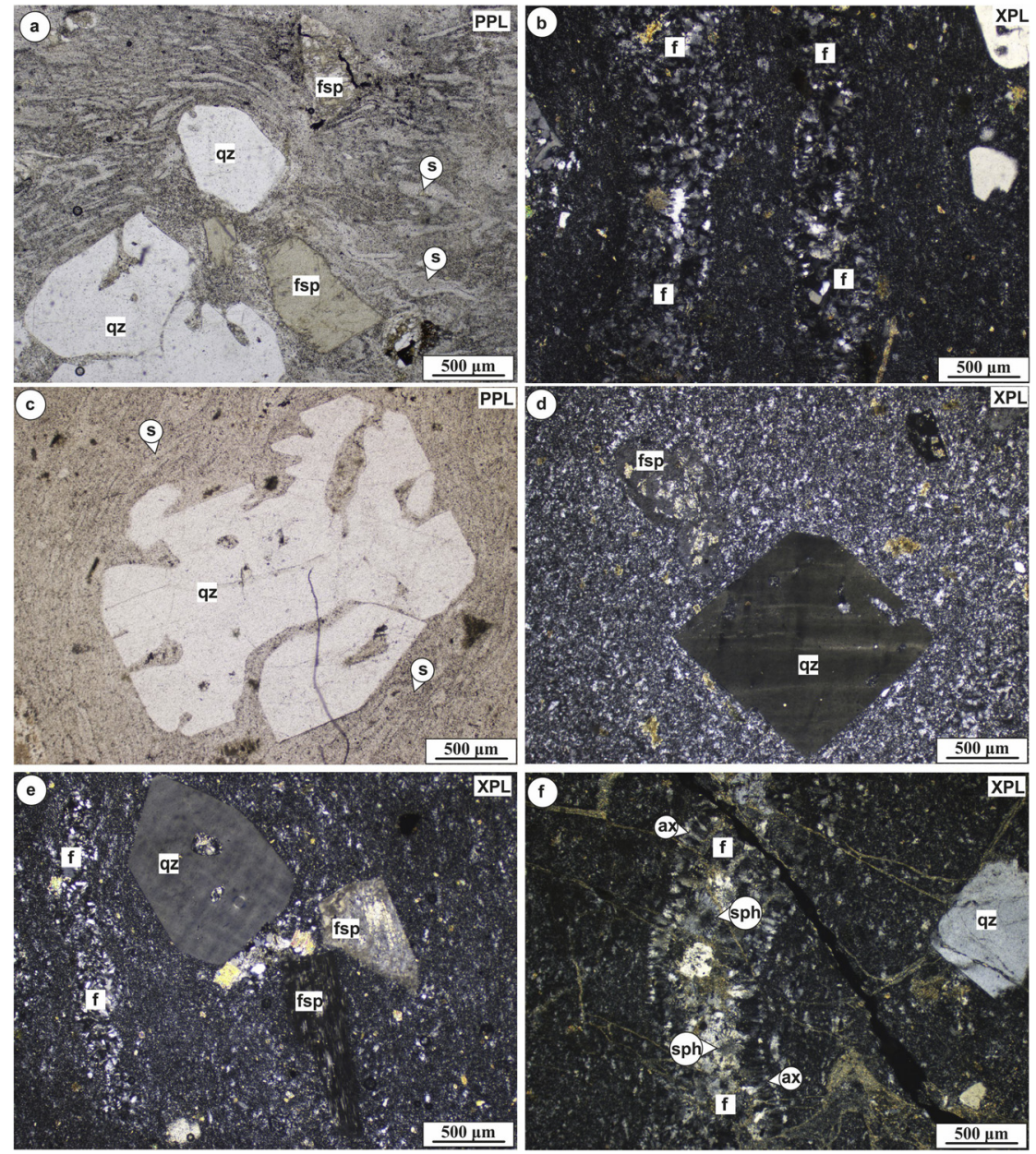

Figure 3. Photomicrographs of the eutaxitic, massive, matrix-supported, porphyric, fiamme-bearing lapilli tuffs (emLT), Battonya area. (a) Sample ÁGK-1830, eutaxitic texture defined by deformed, elongated glass shards with subhedral quartz and feldspar phenocrysts. (b) Sample ÁGK-1830, oriented, devitrified fiammes replaced by mosaic of quartz and feldspar microcrysts. (c) Sample ÁGK-1821, subhedral, resorbed, porphyric quartz surrounded by deformed glass shards. (d) Sample ÁGK-1821, subhedral quartz crystal with deformation lamellae. (e) Sample ÁGK-1830, subhedral, resorbed quartz, K-feldspar (above), and plagioclase (below) phenocrysts and devitrified fiamme replaced by mosaic of quartz and feldspar. (f) Sample ÁGK-1831, devitrified fiamme with axiolites at the rims and spherulites inside it, in a brecciated sample. Abbreviations: ax: axiolite, f: altered fiamme, fsp: feldspar, qz: quartz, s: altered glass shard, sph: spherulite, PPL: plane polarized light, XPL: crossed polars 
size of the fiammes; Fig. 3a and c) and devitrified fiammes (from several $\mathrm{mm}$ in size up to $1.5-2.5 \mathrm{~cm}$; Fig. $3 \mathrm{~b}$, e, and $\mathrm{f}$ ). In the fiamme rims, axiolites are common, whereas rare spherulites occur inside it (Fig. 3f). Fiammes and altered glass shards in the fine groundmass are replaced by mosaic quartz and feldspar (Fig. $3 \mathrm{~b}$ and e). Inside the larger fiammes quartz and feldspar crystals (from 200 to $300 \mu \mathrm{m}$ up to 1 $\mathrm{mm}$ ) and secondary minerals (e.g., carbonate, sericite, and opaque minerals) are also present.

The major mineral assemblage consists of predominantly subhedral, rarely euhedral quartz (42-43 vol\%) and K-feldspar (28-36 vol\%), together with plagioclase (22-27 vol\%) and very rare biotite as a mafic component ( $<1$ vol\%). Quartz crystals (up to $3 \mathrm{~mm}$ ) are usually resorbed (Fig. 3a, c, and e), but rarely euhedral (Fig. 3d) phenocrysts with straight extinction; smaller crystalloclasts (broken, shard-like crystals) also appear. It is important to note that some large quartz crystals show a characteristic deformation feature (i.e., deformation lamellae; Fig. 3d). K-feldspar crystals (up to $5 \mathrm{~mm}$ ) are usually resorbed, fragmented, and moderately altered (sericitized, carbonatized; Fig. 3a and e), showing Carlsbad twinning. Some K-feldspar with overgrowth (Kfeldspar as well) on their resorbed margin are also present. Polysynthetic twinned euhedral or subhedral plagioclase (Fig. 3e) crystals (up to $2 \mathrm{~mm}$ ) as well as opaque pseudomorphs of euhedral biotite crystals (up to $\sim 600 \mu \mathrm{m}$ ) are less common. As an accessory component, small $(<100 \mu \mathrm{m})$ subhedral or euhedral zircon crystals occur in the fine groundmass. Some samples from the Battonya- 60 borehole are strongly brecciated that destroyed the primary texture (Fig. 3f).

Interpretation. The major mineral assemblage (predominantly quartz and $\mathrm{K}$-feldspar, less plagioclase and rare biotite) of the rocks suggests a rhyolitic composition. The unsorted massive appearance points to a pyroclastic flow (ignimbrite) origin. Oriented, eutaxitic texture indicates high-temperature plastic deformation of the vitroclasts (both pumice and glass shards; e.g., Gifkins et al. 2005a, b). Strong devitrification affected the juvenile fragments, creating high temperature crystallization domains (HTCDs; Breitkreuz 2013). This effect is demonstrated by spherulites inside the fiammes and axiolites at their rims (Fig. 3f). Additionally, incipient to strong welding is indicated by the flattened fiammes and sintering glass shards that determines the observed orientation of the rocks (e.g., Gifkins et al. 2005a, b; Fig. $3 a$ and b), corresponding to the eutaxitic texture mentioned above. Purplish gray color of the macroscopic samples indicates the oxidation of the Fe-phases at high temperature during welding, while the greenish tones point to different degrees of subsequent mineralization (e.g., the formation of celadonite and/or chlorite during secondary alteration processes).

\section{Felsitic, matrix-supported, porphyric, fiamme-bearing rheomorphic lapilli tuffs (rheoLT)}

The presence of the rheoLT lithofacies was demonstrated in eight boreholes in the study area, namely wells Battonya-4,
Battonya-25, Battonya-31, Battonya-34, Battonya-52, Battonya-53, Battonya-55, and Battonya-61 (see details in Table 1) in the Battonya-Pusztaföldvár BR, Békés-Codru Unit (Fig. 1c).

Description. The samples of this group are purplish or greenish-gray in color, and can be classified as massive nonporous matrix-supported felsic volcanic rocks, having a similar mineralogical composition (20 vol\% phenocryst content: $61 \%$ quartz, $23 \% \mathrm{~K}$-feldspar, and $16 \%$ plagioclase) as the emLT lithofacies (Fig. 3). Crystalloclasts are less common compared to the former lithofacies. The groundmass (70 vol\%) predominantly contains fine-grained homogeneous mosaics of quartz, feldspar, and sericite (Fig. 4ac). However, in some parts (e.g., around coarser phenocrysts or separately in the matrix), mm-sized oriented patches (10 vol\%, up to $2-2.5 \mathrm{~mm}$ ) of coarser (150-200 $\mu \mathrm{m})$ groundmass crystals with the same composition, showing no definite, sharp edge and rarely spherulites inside them, do occur (Fig. $4 \mathrm{~d}-\mathrm{f}$ ). The mentioned patches (Fig. $4 \mathrm{~d}-\mathrm{f}$ ) of predominantly quartz and feldspar bear well-visible orientation that could barely be observed macroscopically but always in thin sections in crossed polars (Fig. 4). On the other hand, such an orientation could be observed neither in the fine-grained part of the groundmass (Fig. $4 \mathrm{a}-\mathrm{c}$ ) nor in plane-polarized light in the whole material. According to the observed features, these rocks have a predominantly felsitic, porphyric texture (Fig. $4 \mathrm{a}-\mathrm{c}$ ); however, the oriented patches of coarser groundmass crystals, resembling altered fiammes, show eutaxitic characteristics (Fig. $4 \mathrm{e}$ and f). These two distinct textural features can be commonly observed in one thin section next to each other as is displayed by a representative sample in Fig. 4.

Interpretation. The major mineral assemblage with predominant quartz and K-feldspar phenocrysts suggests the same rhyolitic composition. However, the genetic interpretation (pyroclastic rocks or lavas) of the samples is rather difficult. Parts showing felsitic, porphyric texture with homogeneous groundmass and resorbed, large phenocrysts resemble silicic lavas, apparently suggesting a coherent lava facies origin (McPhie et al. 1993; Fig. 4a-c). However, the mm-sized oriented patches of coarser (150$200 \mu \mathrm{m})$ quartz, feldspar, and sericite crystals in the groundmass with no definite, sharp edge (Fig. 4d-f) could be interpreted as the remnants of devitrified fiammes. Based on the observed features, including the lack of vitroclastic texture and lithic clasts, low crystal breakage, but the presence of lineations (devitrified fiammes), the most feasible is that these samples are high-grade rheomorphic ignimbrites (Branney and Kokelaar 1992; Branney et al. 1992; Henry and Wolff 1992). As the result of rheomorphism and/or devitrification, vitroclastic features (i.e., well-visible altered glass shards in the groundmass) are lacking; however, the orientation of the flattened devitrified fiammes (Fig. 4) indicates a rheomorphic flow that postdates or might have occurred during the ignimbrite emplacement and deposition (Branney et al. 1992; Henry and Wolff 1992). Each step of the spectrum can be seen in Fig. 5 from eutaxitic welded ignimbrites (emLT 
lithofacies), having a vitroclastic texture with evident altered fiammes and glass shards (a-b) to high-grade rheomorphic ignimbrites ( $-\mathrm{f}$ ) with barely recognizable remnants of fiammes. Thus, the samples of the rheoLT lithofacies could represent the same ignimbrite sheet as the emLT lithofacies; however, they were formed along slightly different (i.e., higher) temperature and compositional circumstances, e.g., lower volatile content, minimizing the amount of vesiculation, resulting in low explosivity of the eruptions (low crystal breakage) in the Battonya area (Henry and Wolff 1992).

\section{Matrix-supported, fine-grained, felsitic ash tuff with coated particles (accfrichT)}

The presence of the accfrich $T$ lithofacies was demonstrated only in one borehole in the study area, namely the Battonya-
7 borehole (see details in Table 1), Battonya-Pusztaföldvár BR, Békés-Codru Unit (Fig. 1c).

Description. The crystal-poor (quartz: 2 vol\%, K-feldspar 8 vol\%) sample shows a fine-grained felsitic groundmass (89 vol $\%)$ of quartz, feldspar, and sericite with good sorting; however, it differs from all the other samples of the Battonya area in containing $\mathrm{mm}$-sized coated particles (armored pellets, formed around porphyric quartz crystals, 1 vol\%; Fig. 6a-c). The size of the particles ranges between $0.8 \mathrm{~mm}$ and $1.7 \mathrm{~mm}$ (but never reaches the lapilli size: $2 \mathrm{~mm}$ ), while the quartz crystals in the center range between 0.5 and $0.8 \mathrm{~mm}$.

Interpretation. Armored lapilli and pellets are typical in pyroclastic fallout, flow, and surge deposits formed by ash accumulation around coarser crystals (in this case porphyric quartz) under wet conditions (Brown et al. 2012). In this way the sample could be associated with the ignimbrite lithofacies (emLT and rheoLT), most possibly formed in a pyroclastic ash cloud (air-fall ash deposit). Good sorting of
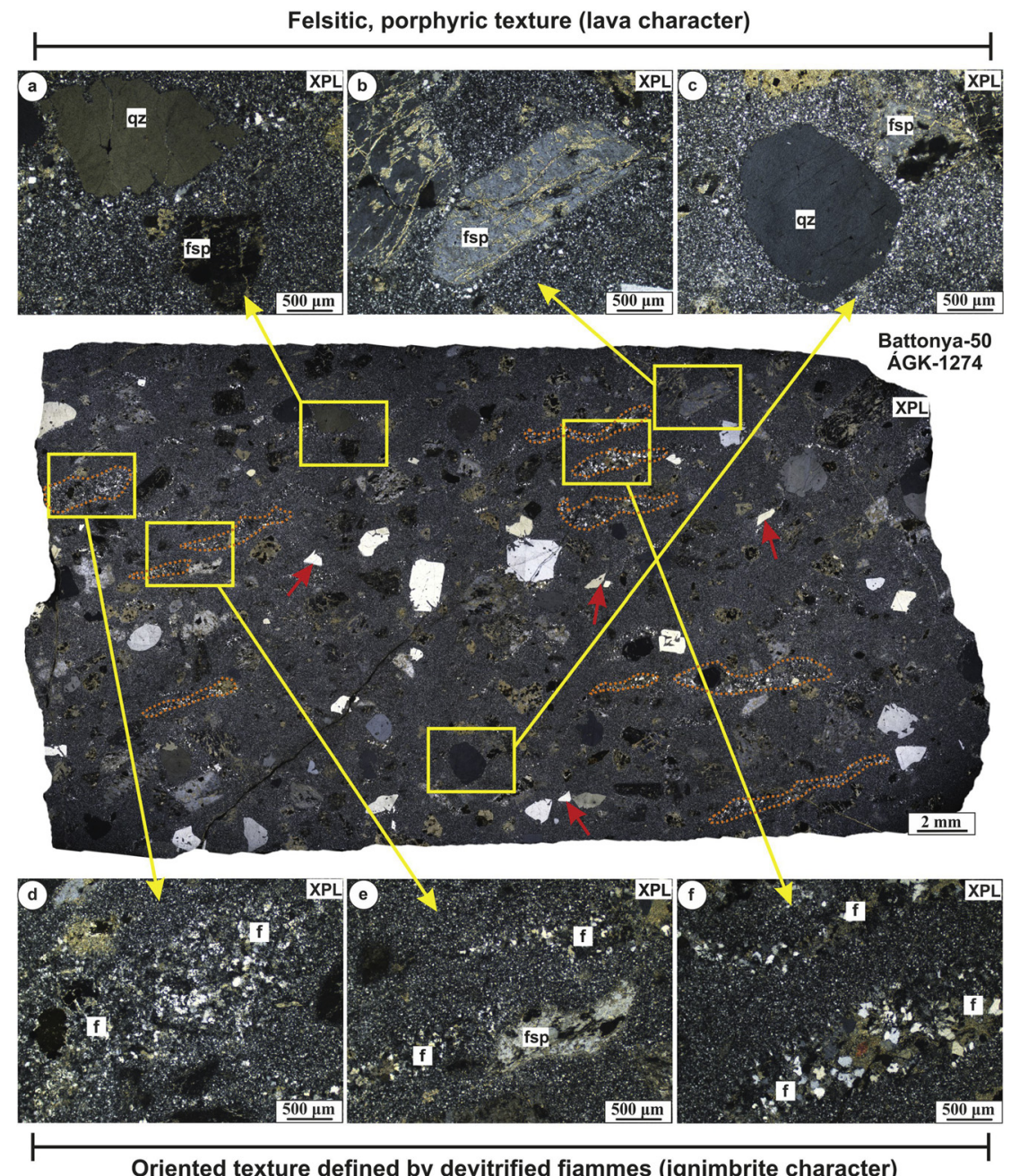

Figure 4. Photomicrographs of the felsitic, matrix-supported, porphyric, fiamme-bearing rheomorphic lapilli tuffs (rheoLT), Battonya area, sample ÁGK-1274 (Battonya-50 borehole), highlighting apparent coherent texture (a-c) and oriented (eutaxitic) parts (d-f) of the sample. $(\mathrm{a}-\mathrm{c})$ Homogeneous groundmass with mosaics of quartz and feldspar microcrysts (crystalloclasts and devitrified glass shards) and subhedral, resorbed phenocrysts. (d-f) Remnants of oriented fiammes indicating rheomorphic flow that postdate or might have occurred during the ignimbrite emplacement and deposition. Note: significant differences in the size of the phenocrysts and the presence of some angular, broken crystals (crystalloclasts pointed by red arrows). Abbreviations: f: altered fiamme, fsp: feldspar, qz: quartz, XPL: crossed polars 

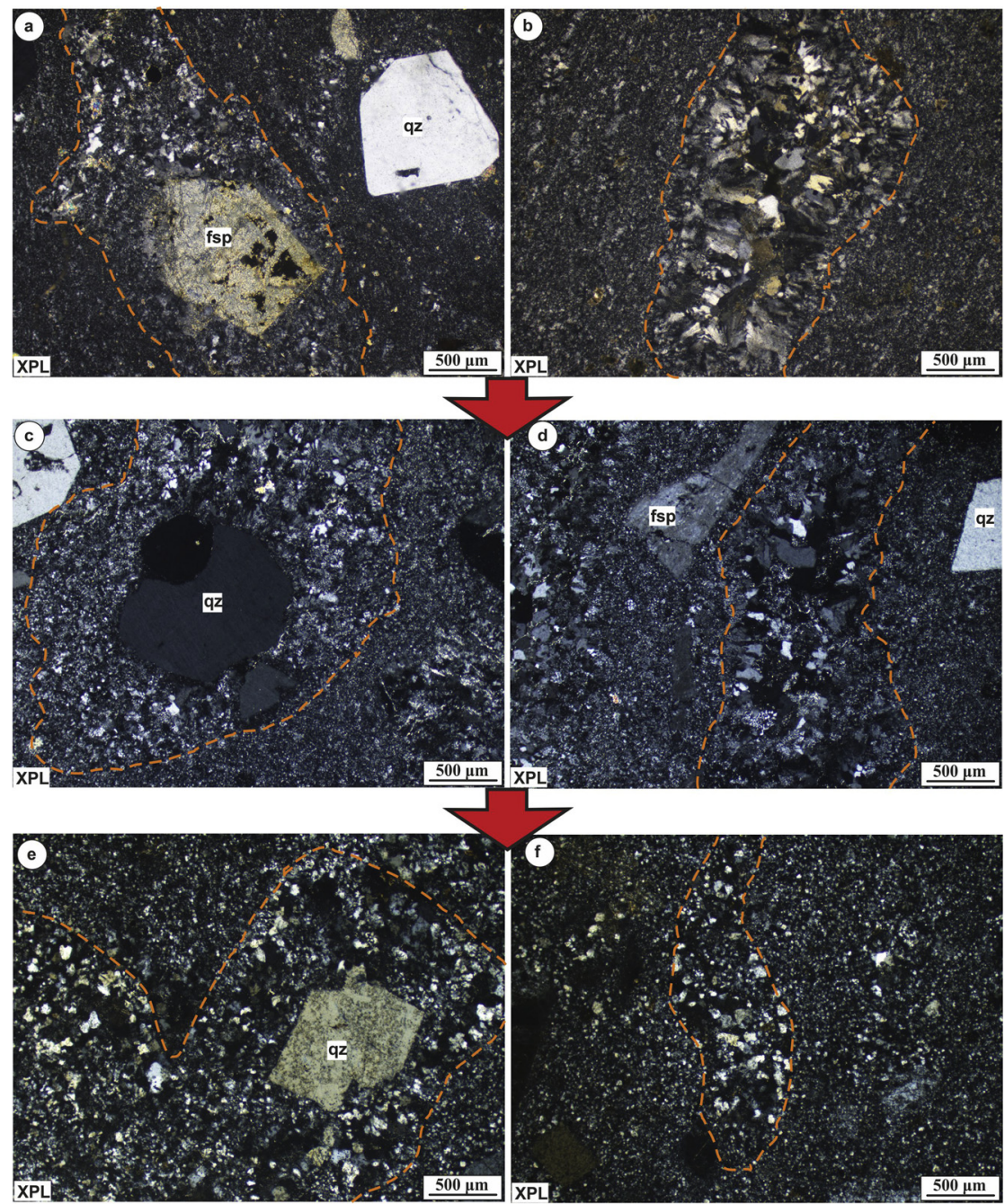

Figure 5. Photomicrographs showing the states of the ignimbrite grade continuum from eutaxitic welded ignimbrites to high-grade rheomorphic ignimbrites (emLT and rheoLT). (a-b) Eutaxitic ignimbrites (emLT, sample ÁGK-1830 and 1821, respectively), containing fiammes with well-visible, definite edge and fine-grained groundmass crystals (devitrified glass shards and crystalloclasts). (c-d) Moderately rheomorphic ignimbrites (rheoLT, sample ÁGK-1790), containing fiammes with visible edge and coarser groundmass crystals. (e-f) Strongly rheomorphic, extremely high-grade ignimbrites, containing fiammes with barely visible edge and coarser groundmass crystals (rheoLT, sample ÁGK-1243). Abbreviations: fsp: feldspar, qz: quartz. XPL: crossed polars. Altered, devitrified fiammes are highlighted by orange dashed lines

the sample (contrary to the poorly-sorted ignimbrites; emLT and rheoLT) also strengthens the aforementioned genetics. Armored pellets are absolutely unique not only regarding the samples of the Battonya area but also all Permian ignimbrites of the Tisza MU.

\section{Lithic-rich, massive, strongly sericitized, poorly-sorted volcaniclastics (ImLT)}

The presence of the $\operatorname{lmLT}$ lithofacies was demonstrated in two boreholes in SE Hungary, namely the Biharugra-I and the Tótkomlós-K-3 boreholes (see details in Table 1), VillányBihor Unit and Békés-Codru Unit, respectively (Figs 1b and 2).

Description. The samples are purplish or greenish-gray in color, massive non-porous pyroclastic or volcanogenic sedimentary rocks that consist of completely sericitized juvenile fragments (from $\sim 100 \mu \mathrm{m}$ sized glass shards up to
1-2 mm long fiammes; Fig. 7a and f), various fragmented crystals (11-14 vol\%, up to mm size) and subrounded lithics (12-15 vol\%, up to $2-3 \mathrm{~cm}$, but generally around $1-5 \mathrm{~mm}$; Figs $7 \mathrm{e}$ and 8 ) with a wide range of origin in a fine matrix (69-76 vol\%) of sericite, quartz, and feldspar. The mentioned components show very poor sorting in all samples and their proportion is extremely variable.

Very thin bands of sericite up to $\sim 2.5 \mathrm{~mm}$ (showing no preferred orientation) occur in all of the samples (Fig. 7a and f). Randomly oriented $\mu \mathrm{m}$-sized patches of sericite can be found in the fine groundmass as well. The aforementioned components are most possibly altered, devitrified juvenile fragments (the former: altered, sericitized fiammes, the latter: sericitized glass shards).

Generally two different types of phenocrysts and lithics could be distinguished in the mixed material: (1) primary magmatic crystals and felsic volcanic lithics (8-15 vol\%), 

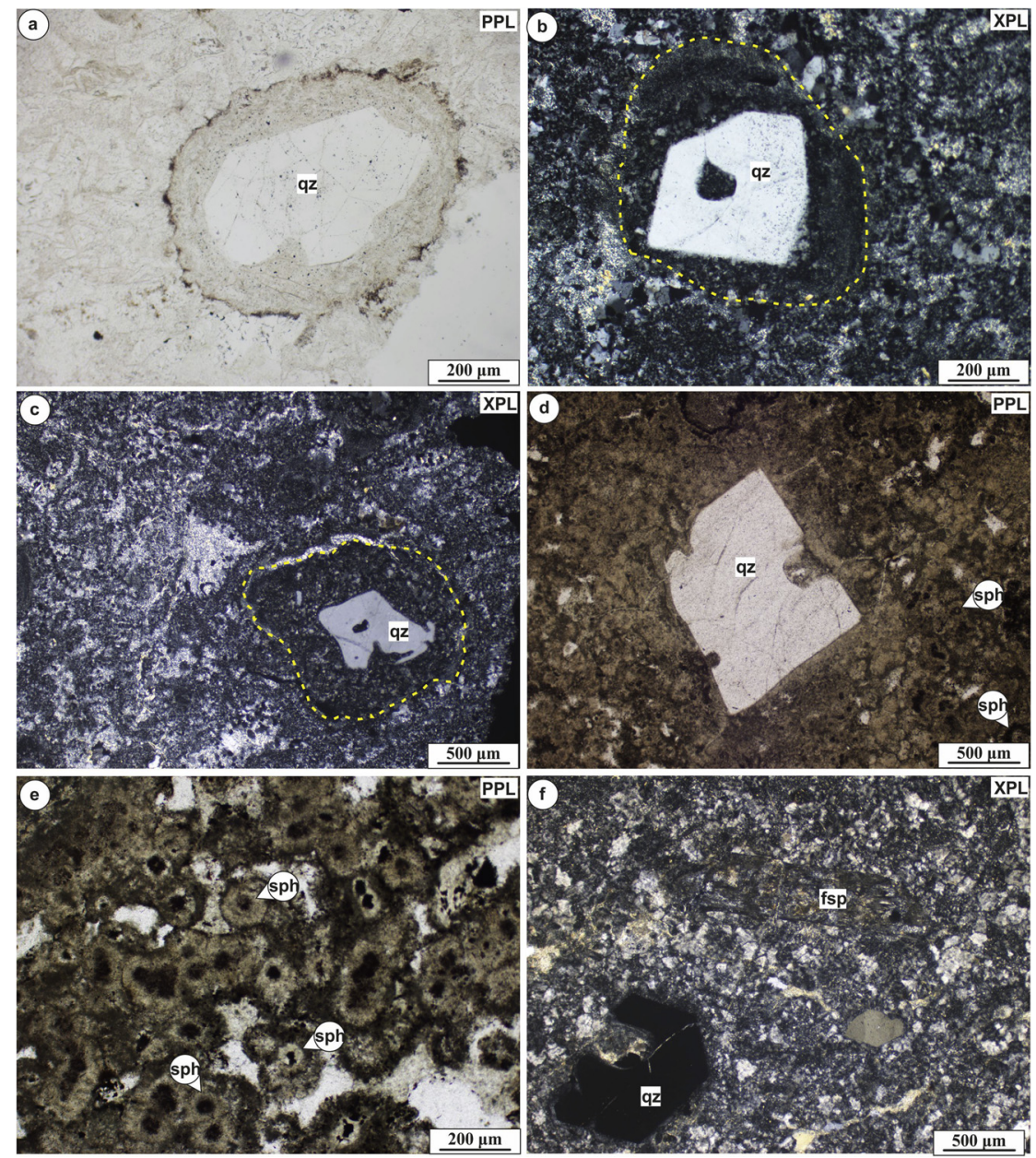

Figure 6. Photomicrographs of the matrix-supported, fine-grained, felsitic ash tuff with coated-particles (accfrichT: a-c) and the spherulitic, vitrophyric lava-like ash tuffs (vlava-likeT: e-f), Battonya and Tótkomlós areas, respectively. (a-c) Sample Bat-7 (Via-79), coated particles (armored pellets) formed around subhedral, resorbed quartz crystals. (d) Sample T-I 14 MF, subhedral, porphyric quartz and spherulites in the matrix. (e) Sample T-I 14 MF, completely spherulitic groundmass. (f) Sample T-I 13 MF, subhedral quartz and sericitized feldspar crystals in the matrix affected by pervasive crystallization. Abbreviations: fsp: feldspar, qz: quartz, sph: spherulite, PPL: plane polarized light, XPL: crossed polars

suggesting volcanogenic origin and (2) not magmatic or presumably older (plutonic) crystals (e.g., polycrystalline, metamorphic quartz or microcline, respectively) and non-volcanic (e.g., sedimentary or metamorphic) lithics (0-4 vol\%).

Magmatic crystals are porphyric subhedral quartz (59-82 vol\%; Fig. 6b) with straight extinction and many broken, angular fragments (100-200 $\mu \mathrm{m}$; Fig. 7a, d, and f); subhedral, strongly sericitized, often Carlsbad-twinned K-feldspar (13-28 vol\%), and polysynthetic plagioclase (6-13 vol\%, Fig. 7c) with broken feldspar fragments (100-200 $\mu \mathrm{m})$ and euhedral, idiochromatic biotite $(<1 \mathrm{vol} \%$, up to $600 \mu \mathrm{m}$; Fig. $6 \mathrm{~b}$ and d) rarely replaced by opaque minerals. As an accessory component, subhedral broken, fractured zircons (up to $150 \mu \mathrm{m}$ ) also occur in the groundmass. Volcanic lithics (8-15 vol\%) form four main groups: (i) felsic lithics with felsitic or spherulitic texture ( $60 \%$; Figs $7 \mathrm{e}$ and $8 \mathrm{a})$, (ii) quartz-feldspar-biotite porphyric lithics with fine matrix ( 15\%; Fig. 8b), (iii) felsic lithics with recognizable oriented juvenile components (glass shards, smaller fiammes) (pyroclastite; $10 \%$; Fig. $8 \mathrm{c}$ ), (iv) and dark-colored, finegrained, hematitized (mafic-intermediate?) lithics ( $15 \%$; Fig. 8d).

Coarser polycrystalline quartz grains with undulose extinction are also present as well as mm-sized crystals of muscovite (Fig. 7e), microcline (Fig. 7f), and biotite.

Non-volcanic lithics (0-4 vol\%) are the following: finegrained reddish or brownish sedimentary lithics (claystone or siltstone; $230 \%$; Fig. 8e); metamorphic lithics built up by undulose quartz and muscovite (mica schist or gneiss; 15\%) and polycrystalline metamorphic quartz ( $\sim 55 \%$; Fig. 8 f).

Interpretation. Strongly sericitized juvenile fragments (altered glass shards and fiammes) have an unequivocally pyroclastic origin. The lack of preferred orientation of the pyroclastic material suggests non-welded texture. Crystals could be primary magmatic such as resorbed, magmatic quartz, K-feldspar, plagioclase, and biotite or derive from older igneous and metamorphic rocks (polycrystalline quartz with undulose extinction, microcline, muscovite). Lithics also represent a wide range of origin; volcanic clasts 


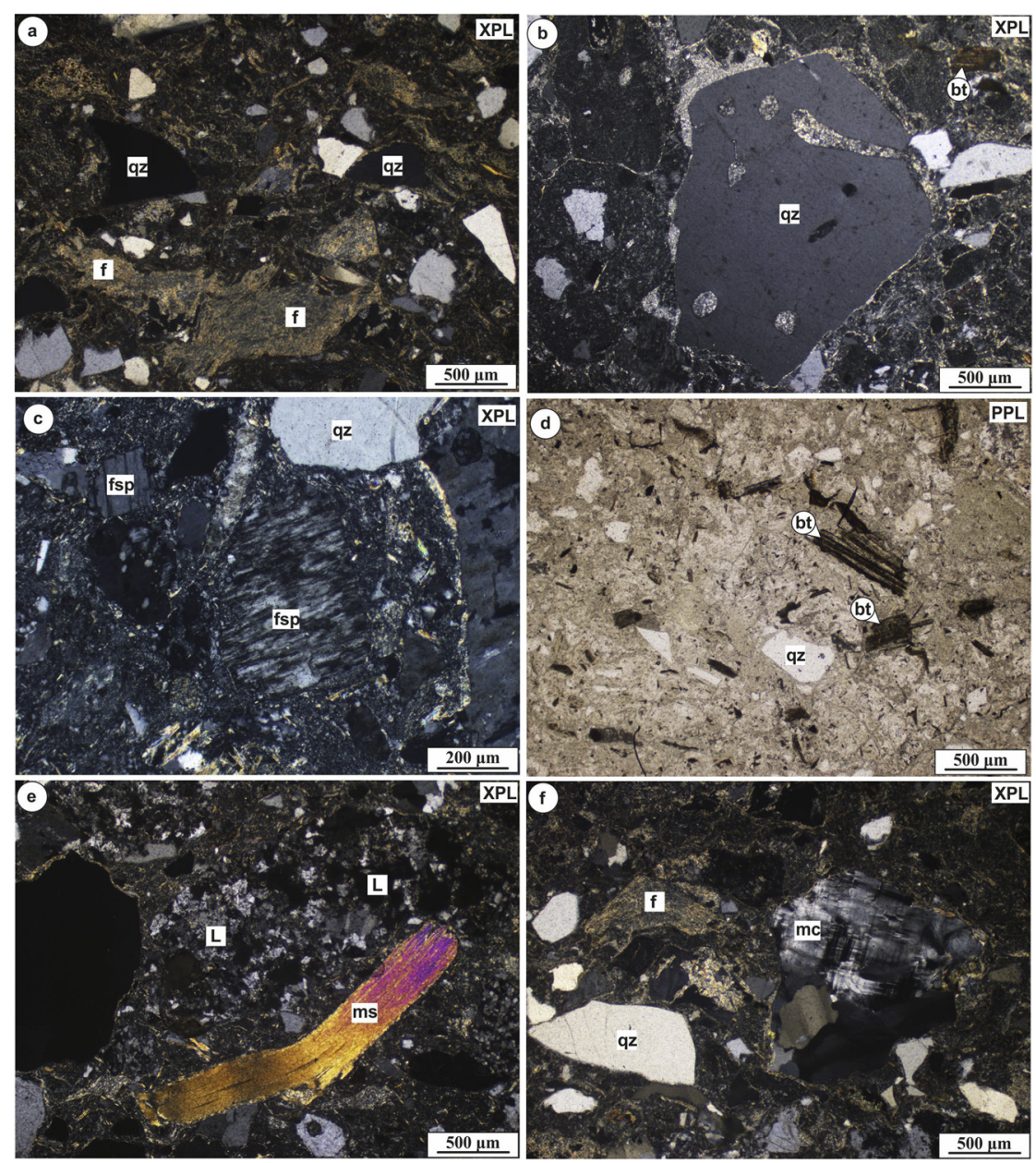

Figure 7. Photomicrographs of the lithic-rich, massive, strongly sericitized, poorly-sorted volcaniclastics (lmLT), Biharugra and Tótkomlós areas. (a) Sample BATR/1, poorly-sorted volcaniclastite, containing sericitized fiammes and angular fragments of quartz. (b) Sample ÁGK1340-2, subhedral, resorbed magmatic quartz and euhedral biotite crystals. (c) Sample ÁGK-1339, subhedral polysynthetic plagioclase (left) and K-feldspar (right) crystals. (d) Sample ÁGK-1340-2, fragmented quartz and euhedral biotite crystals. (e) Sample ÁGK-1267, muscovite and felsic volcanic lithic clast, having felsitic texture. (f) Sample BATR/1, porphyric microcline, broken quartz crystals and sericitized juvenile fragments. Abbreviations: bt: biotite; f: altered fiamme, fsp: feldspar, L: lithic clast, mc: microcline, ms: muscovite, qz: quartz, PPL: plane polarized light, XPL: crossed polars

(Figs $7 \mathrm{e}$ and $8 \mathrm{a}-\mathrm{d}$ ) are more abundant than lithics from the underlying sedimentary (claystone, siltstone) or metamorphic (mica schist or gneiss) rocks (Fig. 8e and f). The chaotic texture with various subrounded lithics, juvenile and crystal fragments suggests that sedimentation and volcanic activity could occur simultaneously. The rocks could be interpreted as resedimented volcanic rocks (Tótkomlós-K-3) or the more mixed material of the Biharugra-I borehole as a volcanogenic sedimentary rock (tuffaceous sandstone according to the grain size; McPhie et al. 1993).

\section{Spherulitic, vitrophyric lava-like ash tuffs (vlava-likeT)}

The presence of the vlava-likeT lithofacies was demonstrated in the Tótkomlós-I borehole (Figs 1b and 2), Békés-Codru Unit. Drill cores from 3 separate depths were observed (drill cores 13-15, see details in Table 1). In this area, corresponding to a separated tectonic block of the basement, the Permian sequence is covered by Mesozoic sedimentary basement formations (Fig. 2). The cores exposed felsic volcanic rocks in a minimum thickness of $156 \mathrm{~m}$; however, they are petrographically rather homogeneous; only the lowest part of the sequence (drill core 15) differs in being strongly deformed in brittle style (brecciated).

Description. Samples of the Tótkomlós-I borehole show vitrophyric texture with 10 vol\% quartz and altered feldspar phenocrysts in a devitrified, completely spherulitic groundmass (90 vol\%; Fig. $6 \mathrm{~d}$ and e). The diameter of the spherulites range between 50 and $100 \mu \mathrm{m}$. On the other hand, no additional textural features (i.e., remnants of juvenile fragments) could be observed. The major mineral assemblage is rather similar to the ignimbrites of the Battonya area with porphyric (up to 1-2 $\mathrm{mm}$ ) euhedral or subhedral quartz (55 vol\%; Fig. 6d and f) and sericitized or carbonatized feldspar crystals (45 vol\%; Fig. 6f), showing low-crystal breakage.

Interpretation. According to the mineralogical composition, the samples of the Tótkomlós-I borehole are rhyolites; 


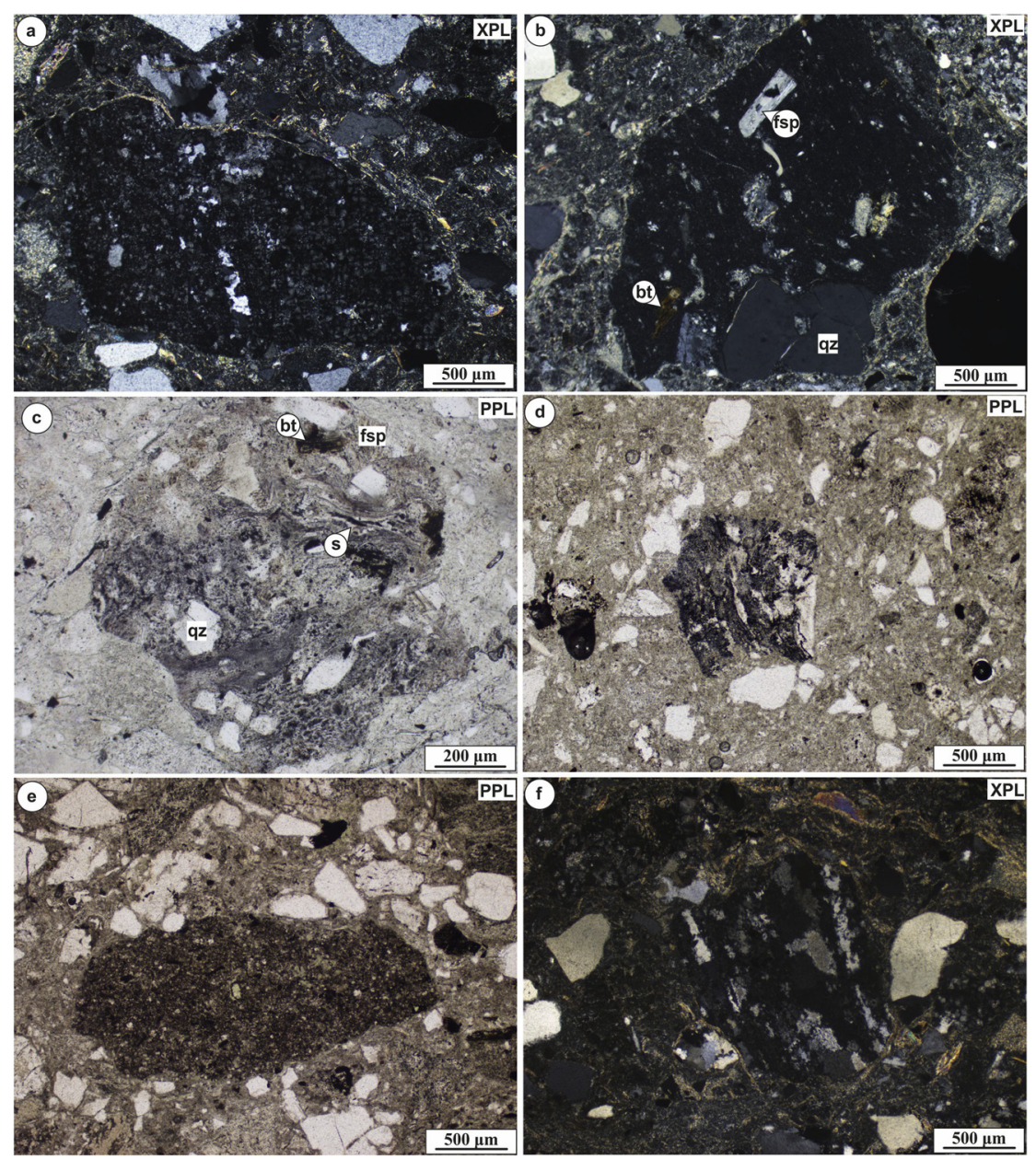

Figure 8. Volcanic (a-d) and non-volcanic (e-f) lithics from the lithic-rich, massive, strongly sericitized, poorly-sorted volcaniclastics (lmLT). (a) Sample ÁGK-1267, felsic lithic clast, having felsitic, spherulitic texture. (b) Sample ÁGK-1340, quartz-feldspar-biotite porphyric lithic clast, having fine groundmass. (c) Sample ÁGK-1339, felsic lithic clast, containing recognizable oriented juvenile components (glass shards); pyroclastite clast. (d) Sample ÁGK-1267, dark-colored, fine-grained, hematitized (mafic-intermediate?) lithic clast. (e) Sample BATR/1, finegrained sedimentary lithic clast (claystone or siltstone). (f) Sample ÁGK-1267, polycrystalline metamorphic quartz. Abbreviations: bt: biotite, fsp: feldspar, qz: quartz, s: altered glass shard, PPL: plane polarized light, XPL: crossed polars

however, their genetic interpretation is very complicated. Spherulitic texture suggests high-temperature crystallization which could be the feature of the inner part of both lavas and welded ignimbrite sheets (Breitkreuz 2013). Although the thickness ( $\sim 150 \mathrm{~m}$, measured from borehole data, Table 1$)$ and some textural features (e.g., spherulites in microcrystalline matrix) are consistent with the central part of silicic lavas (Orth and McPhie 2003), the altered vitroclastic groundmass, broken phenocrystals, and compositional similarity to all the other studied lithologies (i.e., pyroclastic rocks) might indicate a pyroclastic origin. The spherulite and groundmass crystallization could occur in the interior of the unit under moderate cooling conditions ( $\Delta$ T: $50-200^{\circ} \mathrm{C}$, Swanson et al. 1989). Lower breccia zones could generally point to brittle fragmentation near the flow base; however, in this case, taking into consideration the tectonic evolution of the Tótkomlós area (see details of the local faulting in Fig. 2), it is more probable that tectonic deformation and brecciation occurred. In some samples, the entire rock, even the spherulitic matrix, is crosscut by fractures.

\section{DISCUSSION}

\section{Petrographic (re)interpretations according to the new observations and archive reports}

New petrographic observations resulted in a quite different approach to Permian volcanism in SE Hungary. The detailed description and classification of textural features allow us to distinguish between different transport and emplacement mechanisms associated with effusive and explosive eruption styles. Based on the variations in lithology, the studied samples were identified mainly as pyroclastic rocks (predominantly ignimbrites) and volcanic sediments. The textural investigations established the discrimination of two major lithofacies groups: (i) the Battonya area is represented by crystal-poor (8-20 vol\%) welded (with eutaxitic texture: emLT) and rheomorphic ignimbrites with rhyolitic composition that often resemble lavas (rheoLT), while, the other group (ii) consists of 
strongly sericitized, lithic-rich, reworked pyroclastic (probably non-welded ignimbrites) and volcanogenic sedimentary rocks that occur in the Tótkomlós and Biharugra areas, respectively $(\operatorname{lmLT})$.

Interpretation of rheomorphic ignimbrites was difficult as they do not have vitroclastic groundmass and show low crystal breakage. However, oriented and devitrified fiammes in these rocks without sharp, definite edge serve as potential evidence of their rheomorphic origin. Such parts of the samples were previously interpreted as the alternation of volatile-rich and volatile-poor bands within the presumed lava flow by Szepesházy (1967). It is important to note that, in the ca. $60 \mathrm{~km}^{2}$ area (Fig. 1c), all felsic volcanic rocks are derived from similar well depths of the boreholes (Table 1; Fig. 2). Their average minimum thickness is around $20 \mathrm{~m}$ (with no information about the whole thickness of any volcanic sequences near Battonya), and the calculated minimum volume of the volcanic products is $1.2 \mathrm{~km}^{3}$. The lack of characteristic lava-associated facies variations (e.g., no brecciated lava carapace facies) in an area that could be commensurable with a rhyolitic lava flow (or dome) rather points to an ignimbrite sheet that consists of altered crystalpoor, fiamme-bearing lapilli tuffs with rhyolitic composition formed under distinct steps of the ignimbrite grade continuum (Branney et al. 1992; Henry and Wolff 1992). Most possibly, however, only a piece of an ignimbrite sheet was drilled in the Battonya area, as both conventional and rheomorphic ignimbrite sheets are generally much more extensive (their length is up to $\sim 60 \mathrm{~km}$ and max. thickness is $\sim 100 \mathrm{~m}$; Henry and Wolff 1992). The Battonya-7 borehole encountered a pyroclastic rock with armored pellets (around quartz crystals; accfrich T), suggesting its formation in a pyroclastic ash cloud under wet conditions. Beside the fact that such coated particles are so far unique regarding the Permian volcanism of the Tisza MU, they reinforce the explosive origin of the surrounding rocks (i.e., rheoLT facies $<1 \mathrm{~km}$ away). Moreover, Permian volcanic rocks of the Tisza MU are dominantly felsic ignimbrites, while lavas are rather subordinate (Nicolae et al. 2014; Szemerédi et al. 2016, 2017, 2018, 2020).

Reworking of such pyroclastic rocks could result in the volcanogenic sedimentary sequences of the Biharugra and the Tótkomlós areas that are rich in volcanic lithics and sericitized juvenile fragments. These rocks could have been formed in a basin where volcanic and non-volcanic sedimentation occurred at the same time. Such volcanogenic sedimentary rocks are also known from the Western Mecsek Mts within the Cserdi Conglomerate Formation that covers the Permian felsic volcanic rocks in that region (Varga 2009). The various volcanic lithics in $\operatorname{lmLT}$ might suggest multiple-phase Permian volcanic activity that was also documented from the Apuseni Mts (Codru NS; Nicolae et al. 2014). In the Tótkomlós-I borehole, the felsic volcanic rocks (drill cores from three distinct depths) have vitrophyric texture, completely spherulitic groundmass and minor broken crystals. Based on these features (with the lack of altered fiammes) it is not possible to interpret the samples unequivocally (ignimbrites or lavas); however, it is the most probable that they represent the ultimate step of the ignimbrite grade continuum as lava-like ash tuffs (vlavalikeT; Branney et al. 1992; Henry and Wolff 1992). However, being part of a tectonic block separate from the Battonya area (Fig. 2), it is also possible that these samples represent a completely distinct (i.e., younger or older) volcanic episode.

According to the previous petroleum exploration reports (Szepesházy 1967; Kőrössy 2005a) a direct plutonic-volcanic relationship was supposed between the "Battonya quartzporphyry" (thought to be Lower Permian) and the underlying Variscan "Battonya granite." This view was based on the interpretation that the former represents either subvolcanic or surficial lavas that continue as granite towards crustal depths. Our new volcanological interpretation precludes such a direct connection between the ignimbrite and the underlying granite and suggests tectonic or erosional unconformity between them.

\section{Syn and post emplacement textural development}

As ancient volcanic rocks might be affected by various processes of alteration, their primary (syn) and secondary (post emplacement) textural features could be rather difficult to distinguish (e.g., Allen 1988; Branney and Kokelaar 1992; Branney et al. 1992; Henry and Wolff 1992; Gifkins et al. 2005a, b). Based on the petrographic observations of the studied rocks, various lithofacies were distinguished (Table 2); however, some general textural features do deserve additional discussion. All of these features are summarized in Table 5, and the relative timescale of the related processes is displayed in Fig. 9, which is based on several experimental and volcanological case studies (Lofgren 1971; Swanson et al. 1989; Stevenson et al. 1994; Orth and McPhie 2003; Breitkreuz 2015). Primary (magmatic) phenocrysts are similar in all lithofacies, suggesting compositionally similar rhyolitic sources (crystallization above $850-800{ }^{\circ} \mathrm{C}$ and low $\Delta \mathrm{T}$; Swanson et al. 1989). Microcrystalline groundmass of quartz, feldspar, and sericite is also a common feature of the studied samples. Felsitic textures suggest pervasive groundmass crystallization simultaneously and after microlith formation (at high $\Delta \mathrm{T}$; Swanson et al. 1989), while spherulite formation as another type of post emplacement high-temperature $\left(800-500{ }^{\circ} \mathrm{C}\right)$ groundmass crystallization occurred at restricted point sources at moderate $\left(50-150{ }^{\circ} \mathrm{C}\right) \Delta \mathrm{T}$ (vlava-likeT; Swanson et al. 1989; Breitkreuz 2013).

Eutaxitic textures with flattened, deformed, devitrified fiammes and glass shards were formed by welding processes (e.g., Gifkins et al. 2005a, b). Irregular, randomly-oriented devitrified juvenile fragments occurring in the samples of the Biharugra and the Tótkomlós areas suggest the lack of welding processes (non-welded pyroclastic or volcanogenic sedimentary rocks; McPhie et al. 1993; Gifkins et al. 2005a, b). However, the devitrification of juvenile fragments occurred at lower temperatures $\left(<500^{\circ} \mathrm{C}\right)$ than the microlith formation $\left(850-650^{\circ} \mathrm{C}\right)$ or the crystallization of spherulites (Fig. 9; Lofgren 1971; Swanson et al. 1989; Stevenson et al. 1994; Orth and McPhie 2003; Breitkreuz 2015). The 
quenching experiments on Miocene calc-alkaline silicic glasses predicted the solidification temperature around 690-710 ${ }^{\circ} \mathrm{C}$ (Szepesi et al. 2019), while the minimum welding temperature can be reduced by the variations in $\mathrm{H}_{2} \mathrm{O}$ content ( $\sim 600{ }^{\circ} \mathrm{C}$; Quane and Russel 2005).

Volcanic and non-volcanic lithics were ripped by explosive eruptions and represent older components than the host material. Coated particles were formed by ash accumulation around coarser crystals under wet conditions in the ash cloud of eruption or pyroclastic density flow (Brown et al. 2012).

\section{Local and regional correlation}

Based on the Mesozoic evolution (Alpine nappe stacking) of the Tisza MU, the Békés-Codru Unit was correlated with the Codru NS, Apuseni Mts (Szederkényi et al. 2013 and references therein; Fig. 10). Thus, the area of this study (based on the lithological sequence of the Tótkomlós-I borehole) was correlated with the Finiş Nappe, Codru NS (Szepesházy 1979; Körössy 2005a; Fig. 10). Regarding the petrography, however, significant differences were found between the samples of the Codru NS (Finiş, Dieva, and
Moma Nappes, based on Nicolae et al. 2014) and the felsic volcanic rocks of SE Hungary (Békés-Codru Unit). Pyroclastic rocks in the Apuseni Mts are crystal-rich ( $\sim 40$ vol\%) and contain abundant biotite, altered pyroxene, and accessory garnet crystals (Nicolae et al. 2014; Szemerédi et al. 2018). On the other hand, the samples of this study show much lower crystal content ( $8-20$ vol\%); biotite is very rare and no pyroxene or garnet crystals were identified. Neither is any evidence of bimodal Permian volcanic rocks known from the boreholes of SE Hungary, while in the Codru NS cogenetic basalts and subordinate andesites also occur (Nicolae et al. 2014).

Such petrographic differences were also found between the Permian felsic volcanic rocks of southern Transdanubia and the samples of this study. In the Western Mecsek Mts and Máriakéménd-Báta BR, crystal-rich (40-45 vol\%) ignimbrites occur that contain hematitized biotite and strongly altered pyroxene as mafic components (Szemerédi et al. 2016, 2020). At the northern foreland of the Villány Mts similar (biotite and pyroxene-bearing) ignimbrites with accessory garnet are present and they are accompanied by subordinate felsic lavas (Szemerédi et al. 2017).

Table 5. Summary of the most significant textural features observed by each lithofacies of the Permian felsic volcanic rocks in SE Hungary. Abbreviations are listed in Tables 2 and 3. Additional abbreviations: fsp: feldspar, qz: quartz, ser: sericite. The frequency of the distinct textural features is given by the following: $(+)$ : rare, $(++)$ : moderate, $(+++)$ : frequent, $(-)$ : not present

\begin{tabular}{|c|c|c|c|c|c|}
\hline Feature & emLT & rheoLT & accfrichT & $\operatorname{lmLT}$ & $\begin{array}{l}\text { vlava- } \\
\text { likeT }\end{array}$ \\
\hline Microcrystalline matrix & $\mathrm{qz}, \mathrm{fsp}$ & $q z$, fsp, ser & $q z$, fsp, ser & ser, $q z$, fsp & $q z, f s p$ \\
\hline Spherulites & + & + & - & - & +++ \\
\hline Eutaxitic & +++ & + & - & - & - \\
\hline Glass shards & flattened (qz, fsp) & - & - & thin bands (ser) & - \\
\hline Fiammes & flattened (qz, fsp) & flattened (qz, fsp) & - & irregular (ser) & - \\
\hline Broken phenocrystals & ++ & + & - & +++ & + \\
\hline Lithics & - & - & - & ++ & - \\
\hline Non-volcanic lithics & - & - & - & ++ & - \\
\hline Coated particles & - & - & ++ & - & - \\
\hline
\end{tabular}

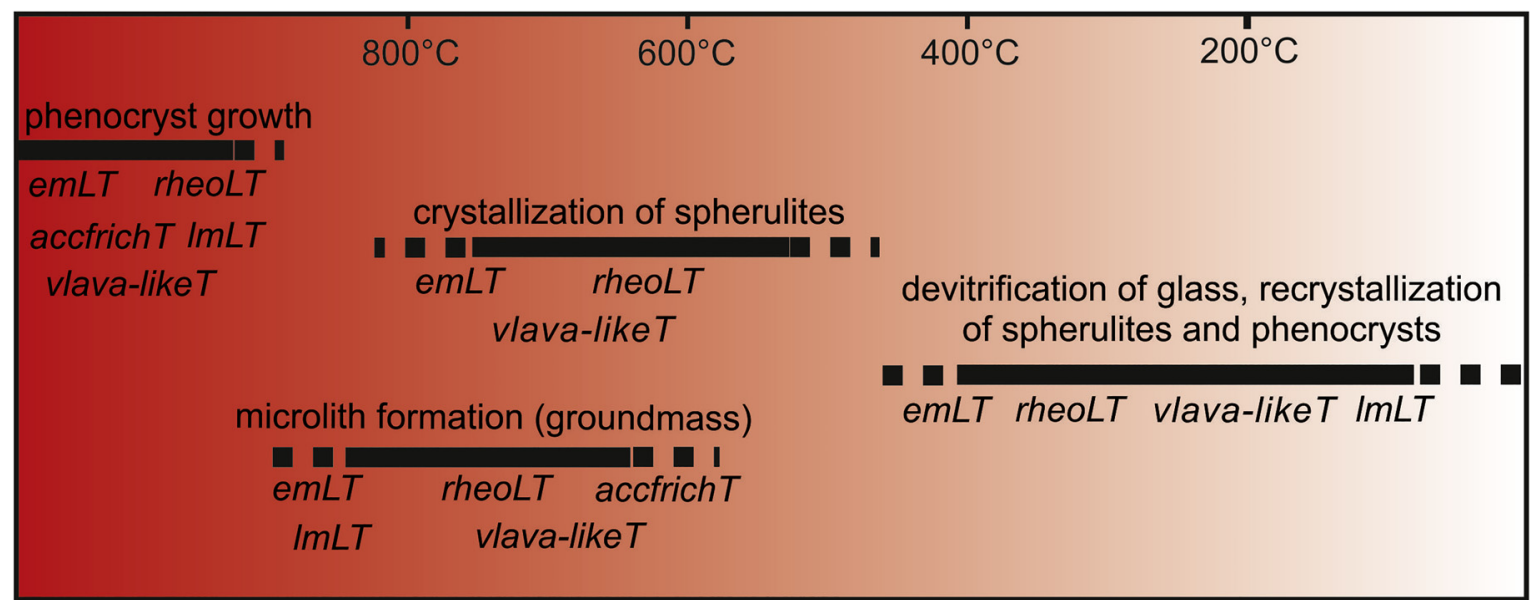

Figure 9. The relative timescale of the most significant processes in textural development of the Permian felsic volcanic rocks. Each process is marked by its representative lithofacies (modified after Lofgren 1971; Swanson et al. 1989; Stevenson et al. 1994; Orth and McPhie 2003; Breitkreuz 2015) 


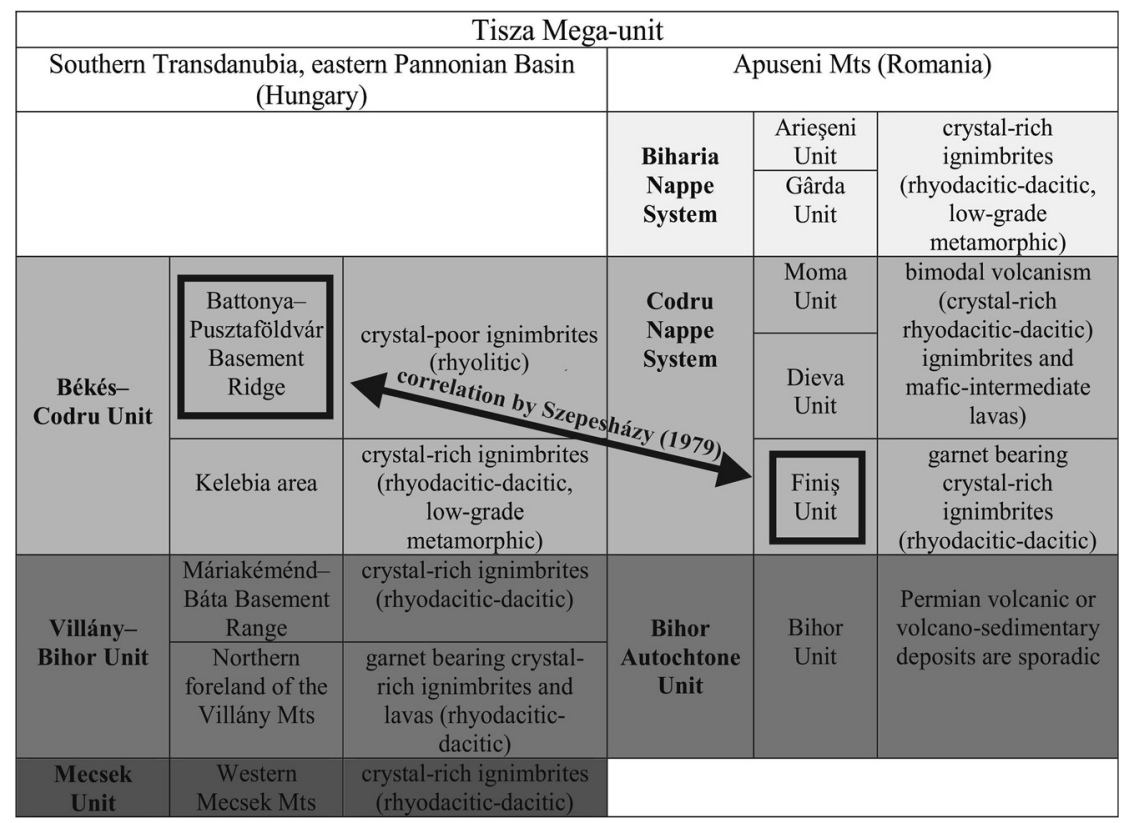

Figure 10. Correlation between the Alpine facies zones of the Tisza Mega-unit (Hungary) and the tectonic units of the Apuseni Mts, highlighting the results of Szepesházy (1979). Data are based on Szederkényi et al. (2013), Nicolae et al. (2014); and Szemerédi et al. (2020)

The mentioned petrographic differences are consistent with the slighter geochemical and geochronological distinctions revealed by our previous studies (Szemerédi et al. 2020). According to the immobile element-based rock classification $\left(\mathrm{Zr} / \mathrm{TiO}_{2}\right.$ vs. $\mathrm{Nb} / \mathrm{Y}$; Winchester and Floyd 1977), felsic volcanic rocks in SE Hungary are predominantly rhyolites (samples of this study), while felsic volcanic rocks from southern Transdanubia and the Apuseni Mts (Nicolae et al. 2014) are rhyodacites-dacites. The immobile element (high field strength elements, rare earth elements) patterns are rather uniform for all Permian volcanic rocks of the Tisza MU; however, the highest values are shown by the samples of SE Hungary in both light and heavy rare earth elements (Szemerédi et al. 2020). Regarding the geochronological results (zircon U-Pb ages), the samples of this study are slightly younger $(259.5 \pm 2.6 \mathrm{Ma}$ from BATR/1 and BATR/2 samples, Tótkomlós-K-3 borehole) than all the other Permian felsic volcanic rocks of the Tisza MU, which range between $263.4 \pm 2.7$ and $266.8 \pm 2.7 \mathrm{Ma}$ (Szemerédi et al. 2020).

\section{Emplacement of the Permian felsic volcanic rocks in SE Hungary within the Permian volcanic system of the Tisza Mega-unit}

The new results suggest that the Permian felsic volcanic rocks in SE Hungary (Battonya, Biharugra, and Tótkomlós areas) might represent the youngest and most evolved, crystal-poor rhyolitic magmas of a large-volume silicic (crystal-rich rhyodacitic-dacitic) volcanism with slighter geochemical, geochronological, and remarkable petrographic differences compared to other Permian felsic volcanic rocks in the Tisza MU. Based on the Alpine evolution of the Tisza MU, the Békés-Codru Unit was correlated with the Codru NS (Apuseni Mts; Fig. 10); however, Permian felsic volcanic rocks in SE Hungary do not show any correlation with similar rock types (felsic ignimbrites) in any nappes of the Codru NS (based on Nicolae et al. 2014): neither the garnet-bearing crystal-rich samples of the Finiş Nappe (as was supposed by Szepesházy 1979), nor the ignimbrites of the Dieva and Moma Nappes that are part of the bimodal volcanic suite (Nicolae et al. 2014). Such crystalpoor ignimbrites are unknown as yet from the Tisza Megaunit and might represent a petrographically and geochemically distinct, younger ( 259 Ma; Szemerédi et al. 2020) episode of the Permian volcanism in the Pannonian Basin.

\section{CONCLUSIONS}

1. Permian felsic volcanic rocks in SE Hungary were previously described and interpreted in the archive reports of petroleum exploration predominantly as lavas ("Battonya quartz-porphyry"). We showed that they are predominantly welded or rheomorphic (Battonya area), rarely lava-like ignimbrites (Tótkomlós-I borehole), and reworked pyroclastic/volcanogenic sedimentary rocks (Tótkomlós and Biharugra areas).

2. Volcaniclastites from the Biharugra and the Tótkomlós areas consist of various felsic volcanic and non-volcanic lithics and might suggest a multiple-phase Permian volcanic activity that was also documented from the nearby Apuseni Mts, Romania (Codru Nappe System; Nicolae et al. 2014).

3. Felsic volcanic rocks in SE Hungary belong to the Permian volcanic system of the Tisza Mega-unit; however, some significant petrographic differences (crystalpoorness, rare biotite, no pyroxene or garnet crystals) 
were observed compared to other Permian felsic volcanic rocks in the Tisza Mega-unit (Nicolae et al. 2014; Szemerédi et al. 2020). Thus, Permian volcanic rocks in SE Hungary might represent the most evolved, crystal-poor rhyolitic magmas of a large-volume silicic (crystal-rich, rhyodacitic-dacitic) volcanic system.

4. In contrast to the previous hypothesis (Szepesházy 1979; Császár 2005), Permian felsic volcanic rocks of the Battonya area do not show any correlations with either the similar samples of the Finiş Nappe, Codru Nappe System, or the Permian felsic volcanic rocks in any nappes of the Codru Nappe System, and there is no relevant plutonicvolcanic connection between the (presumably older) "Battonya granite" and the "Battonya quartz-porphyry."

\section{ACKNOWLEDGMENTS}

The Permian petrographic and correlation studies were supported by the Bolyai Research Scholarship of the Hungarian Academy of Sciences to Andrea Varga. The regional correlation studies were supported by the UNKP17-4, UNKP-18-4-SZTE-16, and UNKP-18-3-I-SZTE-90 New National Excellence Program of the Ministry of Human Capacities (Hungary) to Andrea Varga and Máté Szemerédi as well as by the ongoing National Research, Development and Innovation Fund project K 131690. Additionally, some parts of this research were financed by the Hungarian Scientific Research Fund projects PD 83511, PD 121048, and K 108375 (Hungary) and also supported by the European Union and the State of Hungary, cofinanced by the European Regional Development Fund in the project of GINOP-2.3.2-15-2016-00009 'ICER'. We would like to thank Alexandru Szakács for his suggestions, constructive comments and accurate corrections that improved our manuscript.

\section{REFERENCES}

Allen, R. L. (1988). False pyroclastic textures in altered silicic lavas, with implications for volcanic-associated mineralization. Economic Geology, 83, 1424-1446.

Awdankiewicz, M. (1999). Volcanism in a late Variscan intramontane trough: the petrology and geochemistry of the Carboniferous and Permian volcanic rocks of the Intra-Sudetic Basin, SW Poland. Geologia Sudetica, 32, 81-111.

Barabás-Stuhl, Á. (1988). A Dél-Baranyai dombság és a Villányi hegység permi képződményeinek kutatásáról készített összefoglaló jelentés IV. fejezete a permi képzödményekröl (Chapter IV of the summary report about the research of the Permian formations in South Baranya Hills and Villany Mts.). Mecsekérc Ltd. (former Mecsek Ore Mining Company), Pécs, pp. 100-213 (in Hungarian).

Branney, M. J. \& Kokelaar, P. (1992). A repappraisal of ignimbrite emplacement: progressive aggradation and changes from particulate to non-particulate flow during emplacement of high-grade ignimbrite. Bulletin of Volcanology, 54, 504-520.

Branney, M. \& Kokelaar, J. P. (2002). Pyroclastic density currents and the sedimentation of ignimbrites. Geological Society, London, Memoirs, Vol. 27, p. 143.

Branney, M. J., Kokelaar, B. P., \& McConnell, B. J. (1992). The Bad Step Tuff: a lava-like rheomorphic ignimbrite in a calc-alkaline piecemeal caledera, English Lake District. Bulletin of Volcanology, 54, 187-199.

Breitkreuz, C. (2013). Spherulites and lithophysae - 200 years of investigation on high-temperature crystallization domains in silica-rich volcanic rocks. Bulletin of Volcanology, 75(4): 1-16.

Breitkreuz, C. (2015). Introduction to physical volcanology and volcanic textures. short course guide. TU Bergakademie, Freiberg, p. 55.

Brown, R. J., Bonadonna, C., \& Durant, A. J. (2012). A review of volcanic ash aggregation. Physics and Chemistry of the Earth, 45-46, 65-78.

Cortesogno, L., Cassinis, G., Dallagiovanna, G., Gaggero, L., Oggiano, G., Ronchi, A., Seno, S., Vanossi, M. (1998). The post-Variscan volcanism in the Late Carboniferous-Permian sequences of Ligurian Alps, Southern Alps and Sardinia. Lithos, 45, 305-328.

Császár, G. (2005). Magyarország és környezetének regionális foldtana, I. Paleozoikum-paleogén (Regional geology of Hungary and the surrounding areas, I. Palaeozoic-Palaeogene). Eötvös University Press, Budapest, p. 328 (in Hungarian).

Fülöp, J. (1994). Magyarország geológiája, Paleozoikum II. (Geology of Hungary, Paleozoic II). Akadémiai Kiadó, Budapest, p. 445 (in Hungarian).

Gifkins, C. C., Allen, R. L., \& McPhie, J. (2005a). Apparent welded textures in altered pumice-rich rocks. Journal of Volcanology and Geothermal Research, 142, 29-47.

Gifkins, C., Hermann, W., \& Large, R. (2005b). Altered volcanic rocks: a guide to description and interpretation. University of Tasmania, Hobart, p. 276.

Henry, C. D. \& Wolff, J. A. (1992). Distinguishing strongly rheomorphic tuffs from extensive silicic lavas. Bulletin of Volcanology, 54, 171-186.

Hidasi, T., Varga, A., \& Pál-Molnár, E. (2015). A Gyürüfüi Riolit kőzetmintáinak vizsgálata a Mecseki Ércbányászati Vállalat "Vulkanitok, etalon kollekció" csiszolatgyüjteményének felhasználásával (Petrographic analysis of Gyürüfü Rhyolite Formation using the "Volcanites, etalon collection" thin section collection of Mecsek Ore Company). Földtani Közlöny, 145(1): 3-22 (in Hungarian).

Kőrössy, L. (2005a). Az Alföld délkeleti része kőolaj- és földgázkutatásának földtani eredményei. I. rész (Hydrocarbon geology of the southeastern Great Plain, Hungary. Part I). Általános Földtani Szemle, 29, 41-132 (in Hungarian).

Kőrössy, L. (2005b). Az Alföld délkeleti része kőolaj- és földgázkutatásának földtani eredményei. II. rész (Hydrocarbon geology of the southeastern Great Plain, Hungary. Part II). Általános Földtani Szemle, 30, 7-92 (in Hungarian).

Kurucz, B. (1977). A Pusztaföldvár-Battonya közötti terület medencealjzatának képzödményei és hegységszerkezete (Basement formations and mountain structure of the PusztafoldvárBattonya area). PhD Thesis, University of Szeged, Szeged, p. 137 (in Hungarian). 
Letsch, D., Winkler, W., von Quadt, A., \& Gallhofer, D. (2014). The volcano-sedimentary evolution of a post-Variscan intramontane basin in the Swiss Alps (Glarus Verrucano) as revealed by zircon $\mathrm{U}-\mathrm{Pb}$ age dating and $\mathrm{Hf}$ isotope geochemistry. International Journal of Earth Sciences, 104, 123-145.

Lofgren, G. (1971). Experimentally produced devitrification textures in natural rhyolitic glass. Geological Society of America Bulletin, 82, 111-124.

MacKenzie, W. S., Donaldson, C. H., \& Guilford, C. (1982). Atlas of igneous rocks and their textures. John Wiley and Sons, New York, p. 148.

McPhie, J., Doyle, M., \& Allen, R. (1993). Volcanic textures: a guide to the interpretation of textures in volcanic rocks. University of Tasmania, Hobart, p. 198.

Nicolae, I., Seghedi, I., Boboş, I., Azevedo, M. R., Ribeiro, S., \& TatuM. (2014). Permian volcanic rocks from the Apuseni Mountains (Romania): Geochemistry and tectonic constrains. Chemie der Erde, 74, 125-137.

Ondrejka, M., Li, X. H., Vojtko, R., Putiš, M., Uher, P., \& Sobocký, T. (2018). Permian A-type rhyolites of the Muran Nappe, Inner Western Carpathians, Slovakia: in-situ zircon U-Pb SIMS ages and tectonic setting. Geologica Carpathica, 69/2, 187-198.

Orth, K. \& McPhie, J. (2003). Textures formed during emplacement and cooling of a Paleoproterozoic, small-volume rhyolitic sill. Journal of Volcanology and Geothermal Research, 128, 341-362.

Paulick, H. \& Breitkreuz, C. (2005). The Late Paleozoic felsic lavadominated large igneous province in northeast Germany: volcanic facies analysis based on drill cores. International Journal of Earth Sciences, 94, 834-850.

Quane, S. L. \& Russell, J. K. (2005). Ranking welding intensity in pyroclastic deposits. Bulletin of Volcanology, 67, 129-143.

Repstock, A., Breitkreuz, C., Lapp, M., \& Schulz, B. (2017). Voluminous and crystal-rich igneous rocks of the Permian Wurzen volcanic system, northern Saxony, Germany: physical volcanology and geochemical characterization. International Journal of Earth Sciences, 107, 1485-1513.

Seghedi, I. (2010). Permian rhyolitic volcanism, changinig from subaqueous to subaerial in post-Variscan intra-continental Sirinia Basin (SW Romania - Eastern Europe). Journal of Volcanology and Geothermal Research, 201, 312-324.

Sommer, C. A., Fernandes de Lima, E., Machado, A., May Rossetti, L. M., \& Pierosan, R. (2013). Recognition and characterisation of high-grade ignimbrites from the neoproterozoic rhyolitic volcanism in southermost Brazil. Journal of South American Earth Sciences, 47, 152-165.

Stevenson, R. J., Briggs, R. M., \& Hodder, A. P. W. (1994). Physical volcanology and emplacement history of the Ben Lomond rhyolite lava flow, Taupo Volcanic Centre, New Zealand. New Zealand Journal of Geology and Geophysics, 37, 345-358.

Swanson, S. E., Naney, M. T., Westrich, H. R., \& Eichelberger, J. C. (1989). Crystallization history of Obsidian Dome, Inyo Domes, California. Bulletin of Volcanology, 51, 161-176.

Szederkényi, T. (1962). Földtani jelentés a Ny-Mecseki (Gyürüfü) kvarcporfír földtani, közettani és radiológiai vizsgálatának eredményeiröl (Geological report about the geological, petrological, and radiological results of the Western Mecsek (Gyürüfü) quartz-porphyry). Report, Mecsekérc Ltd. (former Mecsek Ore Mining Company), Pécs, p. 92 (in Hungarian).

Szederkényi, T., Haas, J., Nagymarosy, A., \& Hámor, G. (2013). Geology and history of evolution of the Tisza Mega-unit. In: Haas, J. (Ed), Geology of Hungary. Springer, Berlin, Heidelberg, pp. 103-148.

Szemerédi, M., Varga, A., Lukács, R., \& Pál-Molnár, E. (2016). A Gyürüfüi Riolit Formáció kőzettani vizsgálata a felszíni előfordulások alapján, Nyugati-Mecsek (Petrography of the Gyürüfü Rhyolite Formation, Western Mecsek Mts., Hungary). Földtani Közlöny, 146(4): 335-354 (in Hungarian).

Szemerédi, M., Varga, A., Lukács, R., \& Pál-Molnár, E. (2017). A Gyürüfüi Riolit Formáció kőzettani vizsgálatának eredményei a Villányi-hegység északi elöterében (Petrography of the Gyürüfü Rhyolite Formation, northern foreland of the Villány Mts., Hungary). Földtani Közlöny, 147(4): 357-382 (in Hungarian).

Szemerédi, M., Lukács, R., Varga, A., Seghedi, I., Tatu, M., Dunkl, I., Pál-Molnár, E., \& Harangi, Sz. (2018). Permian volcanism in the Tisza Mega-unit: new petrographic, geochemical and geochronological results from Hungary and Romania. Abstract Book, XXI International Congress of the CBGA, Salzburg, p. 127.

Szemerédi, M., Lukács, R., Varga, A., Dunkl, I., Józsa, S., Tatu, M., Pál-Molnár, E., Szepesi, J., Guillong, M., Szakmány, Gy., Harangi, Sz. (2020). Permian felsic volcanic rocks in the Pannonian Basin (Hungary): new petrographic, geochemical innen egy vesszó lemaradt and geochronological results. International Journal of Earth Sciences, 109, 101-125.

Szepesházy, K. (1967). Közettani adatok a battonyai gránit megismeréséhez (Petrographische Angaben zur Kenntnis des Battonyaer Granits). Annual Report of the Geological Institute of Hungary, pp. 227-266 (in Hungarian).

Szepesházy, K. (1979). A Tiszántúl és az Erdélyi Középhegység (Munţii Apuseni) nagyszerkezeti és rétegtani kapcsolatai (Structural and stratigraphic connections between the basement of the Great Hungarian Plain east of the Tisza River and the Apuseni Mts., Western Transsylvania). Általános Földtani Szemle, 12, 121-198. (in Hungarian).

Szepesi, J., Vona, A., Kovács, I. J., Fintor, K., Buday, T., Scarani, A., \& Harangi, Sz. (2019). Cooling and hydration of the Carpathian obsidian, a differential scanning calorimetry (DSC), thermogravimetry (DTA) and infrared spectroscopy (FTIR) study. Abstract Book, International Obsidian Conference, Sárospatak, pp. 64-65.

T. Kovács, G. \& Kurucz, B. (1984). A Dél-Alföld mezozoikumnál idösebb képzödményei (Formations of the southern Great Plain, Hungary, older than the Mesozoic). Geological Institute of Hungary, Special Publication, p. 57 (in Hungarian).

Kovács, T. G., Varga, A. (2009). A dél-dunántúli paleozoos-alsótriász sziliciklasztos közetek közettani és geokémiai vizsgálatának eredményei (Petrology and geochemistry of the Palaeozoic-Lower Triassic siliciclastic rocks from southern Transdanubia, Hungary). PhD Thesis, Eötvös Loránd University, Budapest, p. 150 (in Hungarian).

Vozárová, A., Šmelko, M., \& Paderin, I. (2009). Permian single crystal $\mathrm{U}-\mathrm{Pb}$ age of the Rožňava Formation volcanites (Southern Gemeric Unit, Western Carpathians, Slovakia). Geologica Carpathica, 60(6): 439-448. 
Vozárová, A., Presnyakov, S., Šarinová, K., \& Šmelko, M. (2015). First evidence for Permian-Triassic boundary volcanism in the Northern Gemericum: geochemistry and $\mathrm{U}-\mathrm{Pb}$ zircon geochronology. Geologica Carpathica, 66(5): 375-391.

Vozárová, A., Rodionov, N., Vozár, J., Lepekhina, E., \& Šarinová, K. (2016). U-Pb zircon ages from Permian volcanic rocks and tonalite of the Northern Veporicum (Western Carpathians). Geologica Carpathica, 61(3): 221-237.

Wilcock, M. A W., Cas, R. A. F., Giordano, G., \& Morelli, C. (2013). The eruption, pyroclastic flow behaviour, and caldera in-filling processes of the extremely large volume $\left(>1290 \mathrm{~km}^{3}\right)$, intra- to extra-caldera, Permian Ora (Ignimbrite) Formation, Southern Alps, Italy. Journal of Volcanology and Geothermal Research, 265, 102-126.

Wilson, M., Neumann, E. R., Davies, G. R., Timmerman, M.J., Heermans, M., \& Larsen, B.T. (2004). Permo-Carboniferous Magmatism and Rifting in Europe. Geological Society, London, Special Publication, Vol. 223, p. 488.

Winchester, J. A. \& Floyd, P. A. (1977). Geochemical discrimination of different magma series and their differentiation products using immobilile elements. Chemical Geology, 20, 325-343. 